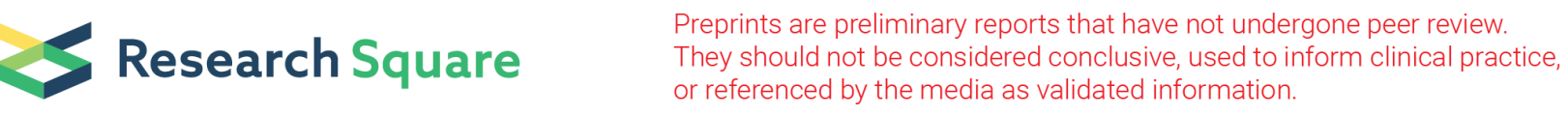

\title{
Higher education institutions and the use of online instruction and online tools and resources during the COVID-19 outbreak - An online review of selected U.S. and SA's universities
}

Chaka Chaka ( $\square$ chakachaka8@gmail.com )

University of South Africa https://orcid.org/0000-0003-3558-4141

\section{Research Article}

Keywords: COVID-19, U.S and South African universities, Social distancing, online transition and online delivery mode, Online tools and resources, Emergency remote pedagogy, Stance and frames

Posted Date: August 21st, 2020

DOI: https://doi.org/10.21203/rs.3.rs-61482/v1

License: (c) (7) This work is licensed under a Creative Commons Attribution 4.0 International License. Read Full License 


\section{Abstract}

This online quasi-scoping review set out to review how 64 U.S. and 21 South African universities pivoted to online course delivery and used online tools and resources as one of their collective responses to continue their teaching and learning activities during the COVID-19 pandemic. The review was conducted on five online search engines, six online databases and two online social networking sites. Generally, all of the U.S and South African universities investigated transitioned to online classes and temporarily relinquished their in-person, campus-based classes. Additionally, all of these universities transiently opted for a strong form of social distancing and embraced emergency remote online pedagogy. Moreover, four online delivery typologies, with their attendant multiple permutations, emerged from these two sets of universities.

Furthermore, when both U.S. and South African universities temporarily pivoted their classes to online delivery during the COVID-19 pandemic outbreak, they embraced and adopted certain online tools and resources more than the others. For instance, pertaining to 64 U.S. universities, Zoom was the most preferred tool, with video conferencing and LMS platforms emerging as the two dominant platforms. As regards the 21 South African universities, Blackboard (Collaborate) emerged as the most preferred tool, with both LMS and video conferencing platforms emerging as the two dominant platforms. Overall, Zoom, Blackboard (Collaborate) and institutional LMSes were the three common tools to which both sets of universities pivoted during the pandemic. Finally, the two sets of universities only embraced low-tech versions of the 4IR technologies such as video-conferencing, social media technologies, and cloud computing.

\section{Introduction}

Throughout human history, pandemic diseases often wreak havoc and leave devastating ruins in their wake. This has been the case with historical and ancient human pandemic diseases (alias plagues). The pandemic of the current novel coronavirus disease-2019 (COVID-19, the illness it causes), which broke out in Wuhan, China, late in December 2019 (Jandrić, 2020; Meng, Hua \& Bian, 2020; Peters, Jandrić \& McLaren, 2020; Vellingiri et al., 2020; Wind et al., 2020; World Health Organization [WHO], 2020), is no different. Often when pandemic diseases of the magnitude of COVID-19, whose infection propensity spirals exponentially, break out, they send communities and societies into a panic mode and instil in them ineluctable fear. This is what COVID-19 seems to be doing: triggering, and drawing humanity into panic reaction globally, and in the process causing unprecedented disruptions. Of course, this type of near-similar human reaction is not entirely unwarranted. It has to be seen in the context in which there is a similar fear-instilling talk that the COVID-19 pandemic threatens to be a black swan virus (Blumenstyk, 2020; Manderson \& Levine, 2020; Ventriglio, Watson \& Bhugra, 2020; Wind et al., 2020; cf. Peters et al., 2020) for humanity. In a different but related instance, Gould and Eldredge (1977) maintained that at different times human populations experience evolutionary changes in short, sudden, and stressful episodes. They referred to this episodic outburst as a "punctuational change" (p. 115) or "punctuated equilibrium" (p. 119). The COVID-19 pandemic seems to be one such episode.

Massive disruptions caused by the COVID-19 outbreak are currently experienced across all human spheres. As a non-expert in epidemiology and medical science, I will focus, in this paper, only on the higher education sector, especially on the response of this sector to the pandemic. In this regard, special attention will be paid to how certain higher education institutions (HEls), particularly selected United States (U.S.) and South Africa universities, 
embraced online instruction and online educational tools and resources as one of their collective responses to delivering teaching and learning during the coronavirus outbreak. The universities that form part of this paper were selected online between 01 February 2020 and 30 April 2020, a time that fell within the COVID-19 outbreak.

Indeed, there is no gainsaying that as the COVID-19 pandemic gathered momentum and spread to more nations, concomitantly affecting more citizens with its fatalities increasing exponentially in different countries, many global universities embraced online learning and online educational tools and resources. In other words, they effectively scrambled to seek life and to find a safe haven online in keeping with the call for social and physical distancing for both students and faculty, their core stakeholders. To this effect, the online space (web pages) was awash with eye-catching headlines such as: 'This is online education's moment' as colleges close during coronavirus pandemic (Bary, 2020); Coronavirus pushes universities to switch to online classes (Houlden \& Veletsianos, 2020); Coronavirus exposes digital disparities between students as learning goes online (Sampathkumar \& Shwayder, 2020); and Coronavirus quarantine could spark an online learning boom (Perrotta, 2020). This was, indeed, a coronavirus moment for global universities, a momentous event aptly captured by Miller (2002, p. 5) as follows: "The coronavirus has colleges and universities swinging into action to move courses online."

In the course of the outbreak of this global pandemic, while the online space has had to deal with many and varied articles dedicated to coronavirus across academic disciplines, just-in-time and bespoke peer-reviewed academic articles published by some of the leading academic and commercial publishers were more notable in the medical science disciplines (see, for example, Gardner et al., 2020; Lai et al., 2020; Meng et al., 2020; Sohrabi et al., 2020; Vellingiri et al., 2020;Wind et al., 2020) than in other academic disciplines. Examples of the latter are social and human sciences and education. Barring the content length and the review process turn-around between journal articles published by medical sciences and those published by the soft-sciences disciplines (which is often shorter in the case of the former and much longer for the latter), some of the leading commercial publishers responded to the coronavirus pandemic in their own clairvoyant and benevolent way. They did so by lifting the pay-forview/access levy that they often charge for accessing their premium articles for a designated period of time during the outbreak of the pandemic (Jandrić, 2020; Peters et al., 2020; The University of Arizona Libraries, 2020; cf. Bates, 2015).

In particular, they did this to facilitate free access to their designated journal articles so as to enable research and scholarship on COVID-19. One classic example is an academic and commercial publisher which had a Novel Coronavirus Information Center on its landing page. The title of this information centre was immediately followed by a tagline: "Elsevier's free health and medical research on the novel coronavirus (SARS-CoV-2) and COVID-19." This tagline was followed by a welcome message: "Here you will find expert, curated information for the research and health community on SARS-CoV-2 (the novel coronavirus) and COVID-19 (the disease)." The information centre was meant for three categories of people: researchers, clinicians, and patients. For researchers, it was pointed out that under the research tab were housed "the latest early-stage and peer-reviewed research on COVID19 from journals including The Lancet and Cell Press." Additionally, it was stated that "more than 21,000 related articles" had been made freely accessible on ScienceDirect. Such articles, the message continued, "are also available to download with rights for full text and data mining, re-use and analyses for as long as needed" (Elsevier, 2020). The current paper is a beneficiary of this journal article fee moratorium (temporary open access) as it was able to access some of these journal articles from home as part of remote working in putting together some of the points it is advancing in support of its argument. 
However, Peters et al. (2020) admonish about the rapid speed with which information - and by extension, knowledge - during the COVID-19 pandemic is shared. To this, one may add, how information is disseminated. Situating their views about viruses, epidemics, quarantining, and health management strategies within viral modernity and bioinformationalism, they argue that some of the current responses to COVID-19 are bioinformationalist in nature. Their concept of viral modernity is predicated on the nature of viruses - human and computer viruses - and the antediluvial and pivotal role they play in human evolution and culture, including the basic application to comprehend the part played by information and forms of information in the social world. This concept, they contend, relates specifically to codes, viral technologies and ecosystems in information, education, publishing, and emerging knowledge (journal) systems. Based on this, they maintain that the current responses to COVID-19 are bioinformationalist in that they signal historically unparalleled levels of sharing information (and knowledge) from genomic sequencing to vaccine testing. At the heart of their views is differentiating between good and bad news (between facts and fake news) in respect of open science during the COVID-19 outbreak (Jandrić, 2020). Their caveat in this regard is instructive and is worth considering.

Even though at the time of writing this paper there was still a paucity of scholarly work published on the impact of coronavirus on higher education, or on education in general, there is a timely education handbook on "undisrupting learning" during the COVID-19 outbreak. The handbook has been put together by seventeen Chinese scholars in partnership with a cohort of international scholars and organisations (Huang et al., 2020; also see Amos \& Howard, 2020; Fernandez \& Shaw, 2020; Jowsey et al. 2020; Lin et al., 2020; Ng \& Peggy, 2020; Viner et al., 2020; Wang, 2020). While this timely and welcome handbook provides a snapshot of innovative and bespoke strategies for delivering teaching and learning at school level in mainland China under the "Disrupted classes, Undisrupted learning" initiative (see Huang et al., 2020) in response to the COVID-19 pandemic, the current paper provides a snapshot of the response of selected HEls to how they offered teaching and learning during the COVID-19 outbreak. It does so by factoring in its online review the now-ubiquitous, and imposing coronavirus mantra of social and physical distancing.

\section{Social Distancing, Stance and Frames as a Theoretical Framing}

With the outbreak of COVID-19, social distance together with its coeval, physical distancing, has emerged not only as a mantra but also as a prism through which coronavirus is viewed. The two phrases have become overnight buzz phrases used as COVID-19 differentiators as compared to other infectious diseases. As used with reference to the coronavirus pandemic, social distancing is the intentional increasing of the space existing between individuals and social groups with a view to avoiding the spreading of COVID-19 infections. This relates, for example, to restricting, cancelling or banning social gatherings, events or sports. Within social distancing parameters is implied physical human distancing in which a minimum space of one meter (six feet) between and around human beings needs to be maintained at any given time (Maragakis, 2020; cf. Aziz, 2020; Ventriglio et al., 2020). The overarching aim of social distancing is to minimise social interactions between individuals so that individuals infected with the coronavirus may not infect those who are still coronavirus-free (Amos \& Howard, 2020; debuglies.com, 2020; Gardner et al., 2020; Morris et al., 2020; Ramsey, 2020; cf. Viner et al., 2020). However, Viner et al.'s (2020) rapid systematic review study found no data on the absolute contribution of school social distancing practices when full school closures were implemented as a transmission control measure during coronavirus outbreaks such as the acute respiratory syndrome (SARS) and the Middle East respiratory syndrome (MERS) in mainland China, Hong Kong, and Singapore. This includes COVID- 19 outbreak in mainland China (cf. 
Amos \& Howard, 2020; Germann et al., 2019; Nicola et al., 2020; Sahu, 2020; Uscher-Pines et al., 2018; Walker et al., 2020; Wang, 2020).

To this effect, one view, among others, is that permutations of social distancing can be implemented in addition to or as opposed to a prolonged wholesale lockdown option during a given period of time. One such permutation is multiple sporadic (intermittent) social distancing stints - also known as staggered forms of social distancing (debuglies.com, 2020; also see Gardner et al., 2020; Ramsey, 2020) or an on/off approach (Kissler et al., 2020) which ebb and flow in keeping with the decrease and spike of the pandemic (Kissler et al., 2020; Powell, 2020; Valdez, Macri \& Braunstein, 2012). In this instance, Valdez et al. (2012) point out the effectiveness of an intermittent social distancing strategy on spreading epidemics in theoretical and real-world adaptive complex networks. Overall, social distancing is part of what Morris et al. (2020, p. 1) refer to as "non-pharmaceutical intervention" strategies intended to decrease "rates of disease-transmitting contact" (also see Gardner et al., 2020, p. 5). Uscher-Pines et al. (2018) refer to it as one of the community-based mitigation strategies. In a different but related context, Ramsey (2020) identifies three types of social distancing: limited, enhanced and strong distancing. Given all of this, social distancing, especially during the epidemic outbreak such as the COVID-19 outbreak, is, the paper argues, a human reaction induced by the fear to contract and transmit coronavirus, and by the need to contain and limit its spread.

But there is a quasi-sociological view of social distance that the paper wants to adopt. This view has two senses to it: a geometric (Euclidian) sense and a metaphoric sense (Ethington, 1997). While the two senses of social distance have complex sociological definitional contours whose unpacking (arguments and counter-arguments) falls outside the scope of this paper, a simplified version of them is provided in this paper. Both geometric and metaphoric social distancing are instances of sociologically theorising the concept of sociality. Briefly stated, a geometric social distance refers to a space that can be represented in metric measurements, while a metaphoric social distance is an imagined social space existing in the mind. The contrast between these two senses can be exemplified as follows: physical versus imagined; and spatial versus symbolic (Ethington, 1997). These two quasisociological dimensions of social distance are incorporated into social distancing as a theoretical framing of this paper.

Two more theoretical constructs are relevant to this paper: stance and frame. Stance is a linguistic device often employed to encode attitude, hedging, attribution, emphasis, and epistemic meanings (Hyland, 1996, 2005; Jalali, 2017). Underlying the conceptualisation of stance is that when a subject (a speaker or a writer) evaluates an object they simultaneously take a stance and position themselves as the subject in relation to the other subject (addressee or reader). This involves a self-other (dis-)alignment in which convergent and divergent positions can be taken by the subject (Du Bois, 2007; Vandergriff, 2012). Stance also embodies meta-stance, a situation entailing framing a previous third-party stance and adopting a stance to the speaker's utterance (Vandergriff, 2012).

The second and last theoretical construct being incorporated into the theoretical framing of this paper is frame. The concept of frame as used here is borrowed from Goffman's (1974) frame theory. In its original conceptualisation a frame is a mental orientation that helps organise human perceptions and interpretations. In this sense, humans can interpret and behave in their environments using frames that are situationally and socially determined. Cognitively speaking, frames are schemata stored in memory whose primary interpretative function is to make sense of existing situations. Additionally, frames comprise many layers that enable humans to simultaneously possess and employ multiple frames (Johnston, 1995; Koon, Hawkins \& Mayhew, 2016; Mertala, 
2019; Omrow, 2018). To this end, they presume that phenomena can be perceived dissimilarly by different individuals, and that both perception and communication embody selectivity and salience. This implies that individuals perceive reality by selecting/foregrounding some aspects of it, while deselecting/backgrounding other aspects of it (Schäfer \& O'Neill, 2017). Based on this framing theorisation, and on the other theoretical constructs mentioned above, the paper views social distancing as embodying geometric and metaphoric senses and as entailing stances and frames.

\section{Online Learning versus Emergency Remote Learning}

Online learning is not a new phenomenon in higher education, especially in the distance education sector. Even for residential, campus-based HEls, there are some of them that often adopt an online learning mode as part of their blended learning ecosystem. Since its incipient days of electronic education (e-education), which saw electronic mail (email) become a disruptive technology and its mid-point time that witnessed the learning management system (LMS) become a legacy learning technology of choice, online learning has radically evolved. However, the uptake of online learning varies with individual HEls and with individual countries (cf. Bates, 2016; Lin et al., 2020; Palvia et al., 2018; Sener, 2010). This section of the paper, nonetheless, is not intended to focus on the successes and failures, the adoption rate, and the unique characteristics of online learning as they pertain to either individual HEls or individual countries. Rather, it is intended to provide a brief characterisation of the differences between online learning and emergency remote learning so as to situate the paper's argument about how selected HEls responded to the COVID-19 pandemic. So, its is not a standard review of related literature, but a fit-for-purpose overview of these two learning concepts in the context of COVID-19, as presently there has not been any precedent to the current coronavirus situation (cf. Meyer \& Wilson, 2011; Peters et al., 2020).

Conventionally, online learning is a web-based e-learning which, in the context of the higher education (HE) sector, is mostly employed by distance education institutions and by certain residential HEIs. In the case of the former, online learning is a lifeline for all matters related to teaching and learning, whereas in the latter case, online learning can be adopted alongside a face-to-face learning mode as part of a blended learning setup. In either case, online learning is deployed as a deliberate and well-coordinated effort born out of an overall institutional plan and embedded in institutional curriculum and pedagogy. Of course, there are multiple definitions of online learning, and at times, the concept is used in distinct and contradictory ways (Singh \& Thurman, 2019). One of the core definitions of online learning articulated by Blackboard Support (1998) that resonates with this paper is that it is a teaching and learning approach that employs Internet technologies meant to communicate and collaborate in a given educational setup (cf. Bates, 2015; Chaka \& Nkhobo, 2019; Darby, 2020; Designing Digitally, 2019; Gannon, 2020; International Association for K-12 Online Learning, 2011; International Baccalaureate Organization [IBO], 2020; Means, Bakia \& Murphy, 2014; Means, et al., 2010; Palvia et al., 2018; Sener, 2010; Xu \& Jaggars, 2013; Zhu \& Liu, 2020). This approach entails: student-student and faculty-student communication; student-centred pedagogies; 24/7-hour course material accessibility; just-in-time strategies to evaluate and assess student progress;and minimising administrivia related to course management (Blackboard Support, 1998).

To this effect, there are commonly-held online learning misconceptions against which Gannon (2020) cautions:

- viewing online learning through the prism of face-to-face learning (also see Bates, 2015, 2020; Hodges, Moore, Lockee, Trust \& Bond, 2020)

- thinking online teaching is less-time consuming than face-to-face teaching

- presence in online learning does not matter as much as is the case with traditional learning. 
By contrast, emergency remote learning $(E R L)$, especially as understood within and applied to the context of the COVID-19 pandemic, refers to urgent and sudden efforts to move face-to-face learning and course materials to emergency remote learning in response to this infectious pandemic disease. The same holds for teaching. The operative words here are urgency, suddenness and emergency, with the first two operative words being occasioned by the last one. A natural human reaction to pandemic infectious diseases is often, the paper argues, fear-, panic-, and instinct-driven (see Ventriglio et al., 2020). Nonetheless, Van Bavel et al. (2020) tend to espouse a different view of panic in pandemic disease outbreaks. As a corollary, it is to be expected that some of the HEls that tried to respond to this pandemic did so following all or any of these three response modes in the initial stages.

Highlighting the move by various HEls in responding to the COVID-19 pandemic in terms of their core academic activities, Hodges et al. (2020) maintain that:

Due to the threat of COVID-19, colleges and universities are facing decisions about how to continue teaching and learning while keeping their faculty, staff, and students safe from a public health emergency that is moving fast and not well understood. Many institutions have opted to cancel all face-to-face classes, including labs and other learning experiences, and have mandated that faculty move their courses online to help prevent the spread of the virus that causes COVID-19. The list of institutions of higher education making this decision has been growing each day. Institutions of all sizes and types-state colleges and universities, Ivy League institutions, community colleges, and others-are moving their classes online (n.p.).

Effectively this quotation encapsulates an urgent, sudden and emergency response by some of the HEls to juggle the health safety of their key stakeholders and the continuity of teaching and learning with the attendant move to migrate classes and course offerings online. Herein lies elements of ERL as spelt out in the preceding paragraph. To this end, Hodges et al. (2020) suggest that shifting to ERL - and to emergency remote teaching (ERT) as well calls for faculty to have more authority over designing, developing and implementing academic courses so as to meet the institutional mandate and in order to ensure instructional continuity (also see Amos \& Howard, 2020; IBO, 2020; Ng \& Peggy, 2020; Wang, 2020). They further point out that ERT (analogously this includes ERL) is an ad hoc and short-term migration of instructional delivery to an alternative delivery mode in response to crisis circumstances (cf. Smalley, 2020). And, one might add here: in a rapid response to special and unavoidable crisis exigency such as the coronavirus pandemic.

In most cases, ERT, Hodges et al. (2020) contend, is deployed in a hurry with scant time and bare minimum resources, resulting in sub-optimal implementation (also see Miller, 2020). To this, they add that the fact that not all faculty members are experts or have the same expertise in online teaching and learning, may undercut the smooth and successful deployment of any ERL/ERT effort. Lastly, they recommend that if ERT is to be evaluated, the focus should be at four pillars of evaluation: context evaluation; input evaluation; process evaluation; and product evaluation. The four evaluation pillars assume the acronym: CIPP. The implication of all the points highlighted here is that ERL is not the same as conventional online learning. The converse implication is that neither is ERT an equivalent of traditional online teaching. So, as the pandemic made its inroad in many countries and spread far and wide, many HEls not only shifted to online learning (Cornock, 2020; Houlden \& Veletsianos, 2020; Mukherjee, 2020; Smalley, 2020; Tutton, 2020; Wang, 2020; cf. Lederman, 2020), but also took to both ERL and ERT (Financial Times, 2020; Grajek, 2020). In this new global setup, both ERL and ERT became almost a new normal. Naturally, when a pandemic breaks out in a world characterised by rapid technological developments in digital tools and apps, and in the area of online teaching and learning, there is an inclination to port or migrate teaching and learning to online platforms, and to upscale online teaching and learning resources (Basilaia \& 
Kvavadze, 2020; Chick et al., 2020; Cornock, 2020; Mian \& Khan, 2020; Sahu, 2020; Surma \& Kirschner, 2020; Taha et al., 2020; Van et al., 2010; cf. Meyer \& Wilson, 2011). However, in all of this, an admonition is made about "panic-gogy" or "panicgogy", which stands for "panic + pedagogy" (Kamenetz, 2020, n.p.), and refers specifically to a panic-driven pedagogy.

\section{Suggested Online Tools and Resources for HEls during the COVID-19 Pandemic}

On 30 January 2020, COVID-19 was declared a "Public Health Emergency of International Concern" by the World Health Organization (WHO) (Mahase, 2020; Meng et al., 2020, p. 1; Sohrabi et al., 2020; WHO, 2020, n.p.; Wind et al., 2020, p. 1). Thereafter, on 11 March 2020, the WHO declared COVID-19 a global pandemic (Duong et al., 2020; Gardner et al., 2020; cf. Viner et al., 2020 [1]). When all of this happened, and as social distancing - especially in the form of national lockdowns - was globally adopted as one of the coordinated non-pharmaceutical interventions to curb and reduce the spread of COVID-19, a raft of suggested online teaching and learning (OTL) tools and resources were offered online. The OTL resources and tools were offered by: certain individuals (e.g., Blackburn, 2020; Darling-Hammond, 2020; Schaffhauser, 2020; Soccolich, 2020); certain tech companies (FutureLearn, 2020; Kahoot!, 2020; Zoom, 2020); some regional bodies (e.g., European Commission [EU], 2020); and given HEls (Najmabadi, 2020; The University of Arizona Libraries, 2020). All of these tools and resources became freely available online during the COVID-19 outbreak. Mostly, they were targeted at differentiated aspects of OTL, and were intended to help HEls mitigate the disruptions to teaching and learning caused by COVID-19 national lockdowns and temporary campus closures. In addition, these OTL tools and resources were meant to facilitate accessibility to digital educational content and help HEls ensure teaching and learning continuity (cf. EU, 2020). Some of these tools and resources were general, while others were sector-specific, and targeted at given segments of a given sector. For example, in respect of the education sector, there were tools and resources for usage by HEls or by schools, or by both. Moreover, some of these tools and resources were distinguishable for the affordances they often provide: video conferencing; chatting; and writing.

It needs to be noted that the online tools and resources mentioned in tables 1, 2 and 3 are just a handful of the examples of such tools and resources. Such tools and resources are many and varied. The same applies to tech companies (small and big) that made their platforms, and their tools and resources available for a limited free use during the COVID-19 pandemic outbreak (see, especially, Blackburn, 2020; Soccolich, 2020).

Again, a noteworthy point is that the classification of OTL tools and resources as provided in the three tables serves as a simple differentiation for the purpose of this paper. That is, the classifications of OTL tools and resources are more complex and nuanced than how the current paper has characterised them. Nonetheless, this simplistic classification is necessary for capturing and foregrounding the pivotal role that OTL tools and resources can play for HEls during the COVID-19 pandemic. In addition, most of the OTL resources and tools displayed on Table 1 are not new: they have been around for some time. What might be new is the repurposed role they are assigned to play and the use to which they need to be put, individually and collectively, for emergency remote learning (ERL) during the coronavirus pandemic.

\section{Research Methodology}


The current study was conducted between 01 February 2020 and 30 April 2020 as an online review. This was two days after the WHO declared COVID-19 a global pandemic - a "Public Health Emergency of International Concern" (Meng et al., 2020, p. 1; WHO, 2020, n.p.; Wind et al., 2020, p. 1). To this effect, it employed a quasi-scoping review design. Conventional scoping review studies have been conducted by scholars such as Arksey and O'Malley (2005), Dijkers, (2015), Hayati et al. (2018), Koon et al. (2016), and Winters, Langer and Geniets (2018; also see Chaka, 2019). There are certain salient stages that a scoping review as opposed to a systematic review has that are relevant for the present study. These are: (a) identifying a research question; identifying relevant studies; (c) study selection; and (d) charting data. These stages constitute a scoping review framework (Arksey \& O'Malley, 2005; Dijkers, 2015; Koon et al., 2016), and were used in much modified versions in the current study in keeping with the purpose of the study. This is one aspect that counts for its quasi-scoping review nature. Most importantly, a conventional scoping review sets out to examine the extent, range and nature of a given research area. Moreover, unlike a systematic review, some of the inherent features of a scoping review are as follows:

- flexible timeline

- broad research question(s)

- post hoc inclusion/exclusion criteria

- clarifying concepts or definitions in the literature

- identifying key aspects or factors related to a concept

- investigating how research is conducted on a given topic of field

- identifying and analysing knowledge gaps

- preference for qualitative synthesis (Koon et al., 2016; Munn et al., 2018).

The current study employed some of the afore-mentioned features in varying degrees. This is another aspect that counts for its quasi-scoping review nature.

\section{Purpose of the review and research questions}

The purpose of this quasi-scoping review study was to review how certain higher education institutions (HEls), especially selected U.S. and South African universities, embraced online learning and which online tools and resources they used as one of their collective responses to delivering teaching and learning during the COVID-19 pandemic. Therefore, it is the view of this paper that a review of this nature is necessary given that the coronavirus pandemic affected different nations differently, rapidly and unexpectedly, and at varying timelines. During this pandemic outbreak, HIEs, like many other institutions, were caught unawares, and their academic activities were severely disrupted (see, Bary, 2020; Houlden \& Veletsianos, 2020; Perrotta, 2020; Sampathkumar \& Shwayder, 2020). This paper, then, seeks to establish how the selected universities responded to the pandemic as they took their teaching and learning activities online. That is, it attempts to provide a snapshot of how such universities responded to this pandemic in terms of their teaching and learning activities, and what online tools and resources they embraced during this pandemic. Against this backdrop, this paper had the following research questions (RQs):

- RQ1 - How did selected U.S. and South African universities respond to the COVID-19 pandemic in terms of their teaching and learning activities?

- RQ2 - Which online tools and resources did they embrace during the pandemic? 


\section{Search strategy}

The search was conducted online as a desktop search between 01 February 2020 and 30 April 2020. The online search strategy started by identifying and selecting universities from the United States (U.S.) and from South Africa. The search strategy consisted of two searches. The first search was conducted on: five online search engines (Bing, Google Search, Google Scholar, Semantic Scholar, and Microsoft Academic); six online databases (Education Resources Information Center (ERIC), Elton B. Stephens Co. (EBSCO), ScienceDirect, Taylor and Francis Online, SpringerLink, and Journal Storage (JSTOR)); and two online academic social networking sites (ResearchGate and Academia.edu. Additionally, and this in line with Viner et al. (2020), the preprint server or repository, medRxiv, was searched (cf. Peters et al., 2020). Search strings were arranged into the following key phrases: U.S. universities AND online teaching and learning AND COVID-19; U.S. universities AND online teaching and learning tools and resources AND COVID-19; and U.S. universities AND emergency remote teaching and learning AND COVID-19. In these search strings, the phrase, "COVID-19", was substituted with "coronavirus".

The same search phrase combinations were used in respect of South African universities, except that the word, "U.S.", was replaced with the phrase, "South African". These were the search strings which, together with their respective permutations, were repetitively queried into the three aforesaid sets of online search platforms. These search strings were combined with the "AND" and "OR" Boolean operators (see Chaka, 2019). Moreover, ancestry or snowball searching was conducted based on the titles and references provided by the returned articles (see Booth, 2016; Nurse Key, 2017; Poirier \& Behnen, 2014; Whittemore \& Knafl, 2005). The first search, yielded among other things, lists of the names of U.S. and South African universities, and articles containing a classification of U.S. universities. For instance, this classification relates to Ivy League schools (prestigious universities, $n=8$ ) and Public Ivy League schools ( $n=8$ ) (Alaimo, 2020; also see Cafee, 2020; Potter, 2019). There were also in-betweeners such as Massachusetts Institute of Technology, Stanford University and California Institute of Technology (Potter, 2019). South African universities do not have such a formally recognised classification even though some universities are regarded and perceived as more prestigious than the others.

The second search was conducted on the websites and portals of both U.S. and South African universities. This search was informed by and based on the information garnered through the first search about these universities. Sixty-four U.S. universities were selected based on U.S. university lists published online (see Association of Public \& Land Grant Universities [APLU], 2020; Stanford, 2020; also see Appendix A). Of these, five were Ivy League universities; five were Public Ivy League universities; and two were in-betweeners. The rest (52) were public and private universities. All of the twenty-one South African universities were public universities. Of these, fifteen were traditional universities, whereas six were universities of technology. Two of the traditional universities were comprehensive universities - universities which are a result of mergers of traditional universities and technikons. Since South African universities are not that many, the ones chosen for this study were selected from their respective websites (see Appendix B).

The scoping review process was conducted following some of the steps and aspects recommended by the Preferred Reporting Items for Systematic Reviews and Meta-Analyses (PRISMA) guide (Beller et al., 2013; Hutton et al., 2015), and following the where and how to search for evidence in the education literature (WHEEL) (Poirier \& Behnen, 2014). For instance, one of the objectives of PRISMA is to ensure clarity and transparency of the search process (see Beller et al., 2013; Hutton et al., 2015).

\section{Data extraction and data analysis}

Page 10/46 
Data sets were extracted from the communiques, announcements, notices, addresses and messages posted on the websites or on the portals of the two sets of universities (see Appendices A and B; also cf. Crawford et al., 2020; Meyer \& Wilson, 2010; Murphy, 2020). These data sets were represented in five separate Microsoft (MS) Word files according to the following broad categories:

- Modes of instruction and their variations adopted by 64 U.S. universities during the COVID-19 pandemic

- Types of online tools and resources utilised by 64 U.S. universities during the COVID-19 pandemic

- Modes of instruction and their variations adopted by 21 South African universities during the COVID-19 pandemic

- Types of online tools and resources utilised by 21 South African universities during the COVID-19 pandemic

- Faculty training and support, student support, reasons for closures, and student offers/concessions

The extracted data sets were subjected to content analysis (see Castleberry \& Nolen, 2018; Erlingsson \& Brysiewicz, 2017). Briefly stated, some of the aspects that content analysis focuses on are: the context of text components; latent structures; distinctive individual cases; (Kohlbacher, 2006); implied textual meanings; emergent themes; coding and representing some data quantitatively (cf. Hsieh \& Shannon, 2005). In the manner in which it is used in this paper, content analysis is about systematically and credibly extracting designated thematic content from data sets The extraction process should be responsive to: answering formulated research questions; making meaning out of the data; and generating bespoke theoretical constructs in line with the data.

An inter-rater reliability of the data extraction process mentioned above was determined by employing Cohen's kappa (к) (Cohen, 1960). This was applied to the rating reliability of three data raters. Cohen's $\mathrm{K}$ is a co-efficient utilised to establish the degree of reliability among raters as informed by kappa coding values. For example, kappa values are weighted as follows: .40 to .60 = fair; .60 to .75 = good; and .75 to 1.00 = excellent (see Chaka, 2019 ; Chaka, Lephalala, \& Ngesi, 2017; Cicchetti, 1994; Zawacki-Richter et al., 2019; cf. Burla et al., 2008; Everitt, 1996). The degree of reliability of the three data raters was $\mathrm{K}=.74$. This value is considered as good according to calibrated $\mathrm{k}$ coding values.

\section{Findings}

\section{United States Universities}

The findings presented in this part of the online review are based on the data extracted from the following sources: online news articles; university websites; the Association of Public \& Land Grant Universities' (APLU) website; and a website of remote teaching resources prepared and managed by Stanford (2020); They are informed by how the datasets were codified as indicated in Tables 4, 5, 6 and 7. Additionally, these findings are in response to the two RQs mentioned earlier.

\section{Modes of instruction and their variations adopted by 64 U.S. universities during the COVID-19 pandemic}

As shown in Table 4, all the U.S. universities explored in this online review embraced and pivoted to online classes during the COVID-19 pandemic outbreak. This move involved contact-less categories of instruction in lieu of inperson instruction. These categories of alternative instruction were temporarily adopted by these universities in keeping with the specific options they preferred as depicted in Table 5. As is evident from this table, these 
categories fell into four broad typologies: online instruction; remote instruction; virtual instruction; and emergency instruction. Of these, online instruction had the highest mention frequency compared to the other three typologies.

Three of these four broad typologies had some permutations, with remote instruction having the most permutations as shown in Table 5. Examples of the permutations of remote instruction are:

- remote learning and teaching

- remote classes

- remote (online) instruction

- remote and online classes

- remote and online learning and teaching

- remote class delivery

- remote course formats

- remote learning and instruction

- remote learning and online services

- remote or online learning and teaching

- remote virtual classes

It is also worth pointing out that all of the remote instruction permutations comprised single variations from 11 universities. In addition, online instruction (together with its permutations) featured predominantly in and was preferred by $35(55 \%)$ of the 64 investigated universities. Instances of its permutations are: online classes; online learning and teaching; on-line or distance teaching and learning; online-only classes; online or remote delivery; and online-only instruction. It is followed by remote instruction, which together with its variations, was referenced 23 times and adopted by $36 \%$ of the universities. This markedly contrasts with virtual instruction and emergency instruction, which did not only have a low uptake among the 64 universities, but also had low mention frequency occurrences. To this end, virtual instruction had only one permutation, whereas emergency instruction had no permutation.

\section{Types of online tools and resources utilised by 64 U.S. universities during the COVID-19 pandemic}

There are various online tools and resources that 63 of the 64 U.S. universities explored in this online review utilised as part of their online instruction migration during the COVID-19 outbreak (see Tables 4 and 6 ). These tools and resources ranged from Zoom, Canvas and Blackboard for the top most used online tools and resources during this period (see Table 6) to Coursera, PlayPosit and Vimeo among the least used tools and resources (see Table 4). Some tools and resources were utilised more than others and, as such, became more prominent than others. To this effect, the two most used and adopted tools were Zoom and Canvas, with the former as the most adopted and utilised tool overall (it was embraced by 58 of the 64 universities), while the latter was the second most used tool. It was embraced by 31 universities. The ten most used tools were: Zoom; Canvas; Blackboard (Collaborate); Panopto; Microsoft Teams; WebEx; Kaltura; Microsoft Office 365; Google Hangouts/Meet; and OneDrive (see Table 6). Of these tools, Zoom exceeds Canvas as the second most utilised tool by 27 more universities that embraced it. Moreover, it exceeds Blackboard (Collaborate) as the third most used tool by 42 universities and OneDrive as the tenth most used tool by 48 universities. 
When the tools performing the same functions are aggregated, two dominant categories emerge: video conferencing platforms and LMS platforms. To this end, the video conferencing platforms emerge as the most utilised platforms. These include: Zoom; Blackboard (Collaborate); Microsoft Teams; WebEx; and Google Hangouts/Meet. Collectively, these five platforms were used and embraced by 109 universities. Of these five platforms, Zoom was adopted by most universities, followed, at a distant second, by Blackboard (Collaborate). Needless to say that Blackboard (Collaborate) straddles both platforms: it serves both as an LMS (Blackboard) and as a video conferencing platform (Collaborate). As the second dominant category, the LMS platforms were adopted and utilised by 59 universities, with Blackboard (Collaborate) as the most utilised. At the lower end are the least utilised tools and resources, which were embraced by only one university (and not by the others) during the outbreak of the pandemic. These include, among others, Vidgrid, OWLbox, Ziteboard, Flipgrid, Houdini FX, Media Space, and Mediathread. A further noteworthy point is that one university did not mention tools or resources it used; one university used one tool (Zoom); and five universities used two tools (Zoom plus one other tool) (see Table 4). By contrast, the rest of the other universities (57 of them) used a suite or a collection of tools and resources: they utilised three or more online tools.

\section{Faculty training and support, student support, reasons for closures, and student offers/concessions}

All universities, except two, offered help, tips, suggestions and guidelines for faculty and students, or for either faculty or students. Some universities provided resources, workshops, trainings and webinars to faculty for pivoting to online instruction. Moreover, all of the 64 universities transitioned to online instruction owing to the COVID-19 outbreak together with its attendant social distancing requirement. Finally, 17 universities provided student offers or student concessions ranging from emergency funding to (loaner) laptops to free access to digital publications.

\section{South Africa Universities}

As is the case with 64 U.S. universities, the findings related to 21 South African universities presented in this part of the online review are based on the data extracted from the following sources: online news articles and university websites. They are informed by how the datasets were codified as indicated in Table 7. Additionally, these findings are in response to the two RQs mentioned earlier.

\section{Modes of instruction and their variations adopted by 21 South African universities during the COVID-19 pandemic}

As depicted in Table 7, all the South African universities explored in this online study transitioned to online classes during the COVID-19 pandemic outbreak. This transitioning entailed contact-less categories instruction in place of the traditional, campus-based instruction. These categories of substitute instruction were transiently embraced by these universities in accord with the specific choices they opted for as illustrated in Table 7. As shown from this table, these categories fell into four broad typologies: online instruction; remote instruction; dual pathway instruction; and emergency instruction. Of these, online instruction had the highest mention frequency compared to the other three typologies. Three of these four broad typologies had some permutations, with online instruction having the most permutations as shown in Table 7. Some of the examples of these permutations are: online learning and teaching; online and distance learning and teaching; alternate online methods; online platforms; online/blended delivery; online instruction; and online classes. Both remote instruction and dual pathway instruction have two variations each. These are remote teaching and learning and multimodal remote learning and 
teaching, and five variations of a dual learning and teaching pathway and mixed teaching and learning delivery methods, respectively. On the contrary, emergency instruction did not have any permutation.

A noteworthy feature here is that all of the online instruction permutations consisted of ten similar permutations and six single variations from 16 universities. Thus, online instruction (and its associated permutations) also featured predominantly in and was preferred by 16 (76\%) of the 21 investigated universities. By contrast, both remote instruction and dual pathway instruction had two permutations apiece. Their permutations were referenced by 2 universities each, while emergency instruction was referenced by one university.

\section{Types of online tools and resources utilised by 21 South African universities during the COVID-19 pandemic}

There are certain online tools and resources that 17 of the 21 South African universities explored in this online review used as part of their transition to online instruction during the COVID-19 outbreak (see Table 7). The tools and resources in question ranged from Blackboard (Collaborate), institutional LMSes, WhatsApp, Zoom and Moodle for the most used online tools and resources during this period to Coursera, Facebook, Kaltura, Sakai and Skype among the least used tools and resources (see Table 7). Of these tools and resources, those in the first set became more salient than the rest. In this regard, the two most adopted and used tools were Blackboard (Collaborate) and institutional LMS platforms, both of which were embraced by 5 universities each, while the tools and resources in the second set were among those embraced by one university.

When the tools utilised to perform the same functions are aggregated, two dominant categories emerge: LMS platforms and video conferencing platforms. To this effect, the LMS platforms emerge as the most utilised platforms. These include Blackboard (Collaborate), institutional LMS platforms, Moodle and Coursera. Conjointly, these platforms were used and adopted by 14 universities. The video conferencing platforms (comprising Blackboard (Collaborate), Zoom and MS Teams), as the second dominant category, were embraced and used by 10 universities. Furthermore, 7 universities employed one tool, whereas 6 universities utilised more than two tools.

\section{Faculty training and support, student support, reasons for closures, and student offers/concessions}

Seven of the 21 universities offered guidelines or orientation to staff. Of these seven universities, one offered a webinar while another one provided training. Three universities provided guidelines or orientation to staff and students, whereas 10 universities did not mention what their circumstances were. One university was in the process of implementing a trial period first. Moreover, all of the 21 universities transitioned to online instruction due to the COVID-19 outbreak and its attendant social distancing requirement. Lastly, 11 universities offered mainly zero-rating of data and of specific institutional websites to students, while 3 universities were still negotiating for data deals with mobile network providers, and one university was to conduct student needs survey. In contrast, 4 universities did not mention tools or resources they used.

\section{Discussion}

As pointed out in the preceding two findings sections, all of the U.S and South African universities explored in this online study pivoted to online classes and temporarily jettisoned in-person classes. They did so as a way of embracing and implementing social distancing as one of the non-pharmaceutical interventions recommended within the COVID-19 response arsenal. This instantaneous online transition is aptly captured by the following sentiment: "As the coronavirus spread, colleges are scrambling to respond to potential health-care crises, campus

Page 14/46 
closings, and other issues ... A growing number are moving classes online as a short-term solution" (The Chronicle of Higher Education [The CHE], 2020, p. 3; also see Burki, 200, p. 758; Miller, 2020, p. 8).

In fact, many HEls during this critical period resorted to online instruction as a solace to ensure and salvage their teaching and learning continuity, and as means to comply with social distancing. They also did so to embrace short-term remote pedagogy. As highlighted in the theoretical framework section, the practice of deploying social distancing measures such as closing learning institutions like schools during pandemic outbreaks seems to be common. For example, scholars such as Germann et al. (2019), Uscher-Pines et al. (2018), and Viner et al. (2020) have investigated such a practice in respect of schools, while Sahu (2020) has recently produced a short review of university closures due to COVID-19. To this end, Germann et al. (2019) conclude, in their study, that school closures serve as the only non-pharmaceutical intervention measure to adopt in responding to an emerging, evolving pandemic. With regard to universities, Sahu (2020) points out that due to the COVID-19 pandemic, many universities across the globe have cancelled or postponed their academic activities, and have, consequently, transitioned to online instructional platforms.

Again, as argued in the theoretical framework, one of the cardinal goals of social distancing that leads to school and university closures during a pandemic is to minimise social interactions between individuals with a view to reducing person-to-person viral infection rates (Amos \& Howard, 2020; debuglies.com, 2020; Gardner et al., 2020; Germann et al., 2019; Morris et al., 2020; Sahu, 2020; Uscher-Pines et al., 2018; cf. Viner et al., 2020). Besides being implemented intermittently, or in a staggered way (debuglies.com, 2020; Gardner et al., 2020; Kissler et al., 2020; Ramsey, 2020), social distancing can have a limited, enhanced or strong form (Ramsey, 2020). With reference to the two sets of universities investigated in the current study, all of them seem to have temporarily opted for a strong form of social distancing (Gardner et al. (2020) since they completely shut down their campuses at the outbreak of the COVID-19 pandemic. This move is evinced by their instantaneous and wholesale transitioning to online pedagogy (see Tables 4 and 7). Nonetheless, it is also possible that social distancing may, at times, be occasioned by the need to minimise social interactions and the evocation of human reactions such as fear, anxiety and panic that are, in turn, triggered by a developing public health emergency (see Manderson \& Levine, 2020; Ventriglio et al., 2020); cf. Van Bavel et al., 2020).

From a quasi-sociological view adopted in this paper, social distancing also entails geometric and metaphoric senses. In relation to the universities under study, metaphoric social distancing is exemplified by communiqués, addresses, notices or messages about campus closures these universities issued to their respective campus stakeholders (e.g., faculty, students and staff) at different times during the outbreak of the COVID-19 pandemic (see Appendices A and B). All of this happened immediately before and after COVID-19 was declared a global pandemic by the WHO on 11 March 2020 (see (Duong et al., 2020; Gardner et al., 2020; cf. Viner et al., 2020). Issuing communiqués about campus closures is an instance of metaphoric social distancing in that it is an act imagined and occurring in the mind that does not entail the actual physical distancing itself. In contrast, geometric social distancing is represented by the action taken by campus stakeholders to vacate their respective campuses in response to campus closure communiqués issued to them. This compliant action of vacating campuses embodies physical and spatial distancing that is measurable in varying spatial degrees.

However, social distancing is inherently disruptive. For instance, in the case of the two sets of universities under study here, the possibility of the disruption (see Duong et al., 2020) to their stakeholders' sociality caused by social distancing when campuses closed down and when they pivoted to online instruction cannot be discounted. This social disruption spilled over to other areas of the universities concerned such as the operations of these

Page 15/46 
universities. Duong et al. (2020) put this disruptiveness, including those of other education sectors, into perspective: "The response to the COVID-19 pandemic has brought a sudden disruption in the operations of schools, colleges and universities, influencing more than 1.7 billion students in 192 countries" (p. 2). By contrast, the upside of social distancing is the new normal that it spawned. One salient feature of this new normal for the universities reviewed in this study is a transitional migration from in-person presence to online presence in terms of teaching and learning (see Tables 4 and 7). To this end, a paper written by two faculty members from one of the U.S. universities examined in the current study talks of how social distancing brought these faculty members and others closer together as a disciplinary community through transitioning to online delivery (Amos \& Howard, 2020). Of course, online course delivery is not necessarily a new normal: it predates the current COVID-19 pandemic.

Moreover, the issuing of campus closure communiqués by these universities was an act of stance-taking. That is, by doing so, each university took a stance vis-à-vis social distancing and, most importantly, vis-à-vis the COVID-19 pandemic. This entailed each university positioning itself in relation to the subject (COVID-19) it was facing as a social institution. This also meant that each university had to align, and not disalign (Du Bois, 2002, 2007; Vandergriff, 2012) itself with communicating and sharing the safety and health requirements attendant to responding to COVID-19 with its stakeholders. In line with Vandergriff's (2012) view, each university's stance entailed framing a third party's stance - e.g., the WHO's and its own government's COVID-19 experts' stance - and adopting a stance to that third party's advice (utterance). This particular stance adopting entails meta-stance.

When the said U.S. and South African universities transitorily transitioned their classes to online delivery during the COVID-19 outbreak, certain typologies of online delivery emerged between them as sets of universities. There were four such typologies for each set of universities: online instruction, remote instruction, virtual instruction, and emergency instruction for U.S. universities; and online instruction, remote instruction, dual pathway instruction, and emergency instruction for South African universities (see Tables 5 and 7). Three of these typologies are shared in common by the two sets of universities. In each set, the first three typologies had permutations with the exception of emergency instruction. Concerning U.S. universities, remote instruction had the most permutations, but online instruction had the highest mention frequency. For South African universities, online instruction had the most permutations and the highest mention frequency. The typologies - together with their permutations imputed to these two sets of universities have been devised based on the nomenclature the universities themselves used to refer to the online class delivery to which they temporarily transitioned during the COVID-19 pandemic outbreak. This embracing of a transitional online educational delivery, especially concerning the U.S universities, contrasts markedly with Meyer and Wilson's (2011) review study of 50 U.S. universities' emergency plans and responses during the H1N1 flu outbreak, which found that only one university (among the 50 universities) mentioned online learning as a solution (cf. Crawford et al., 2020).

These typologies and their associated permutations reflect a specific stance each university in each set took vis-àvis a name it attached to its online class delivery. Stance-taking involves, as articulated by Hyland $(1996,2005)$ and Jalali (2017), encoding attitude, emphasis and epistemic meanings. This means that each name a university attached to its online class delivery, which in turn resulted in a specified typology and its given permutations, conveys that university's attitude towards, its emphasis of, and the epistemic meaning it attached to its own online class delivery. Effectively, embodied in such a stance-taking was the acceptance, on the part of the universities in the two sets, of online pedagogy as a new normal and as emergency remote pedagogy for the transitional period. 
Reflecting on this type of emergency online pedagogy, Murphy (2020) refers to it as "the normalization of emergency eLearning" in which "strategies that frame the widespread adoption of online learning under COVID-19 [are] a pathway to a new normal rather than an emergency response" (p. 9). He further opines that the current COVID-19 response does not constitute the first instance in which emergency eLearning programmes have been pivoted as crisis-response measures. He, then, argues that a similar response was adopted during H1N1, when online classes substituted in-person classes. Moreover, he points out that comparators for COVID-19 can be found in natural disasters such as Hurricane Katrina during which there was "a rapid-deployment of online learning" ( $p$. 5) code-named Sloan Semester (also see Sener, 2010, p. 9; Meyer \& Wilson, 2011). A telling observation from Murphy (2020) pertaining to the current COVID-19 pandemic is that "one common trend in education systems around the world has been to respond to the pandemic with 'emergency eLearning' protocols, marking the rapid transition of face-to-face classes to online learning systems" (p. 1; also see Trust \& Whalen, 2020, p. 189). Given this, it is worth pointing out that the online transitioning that the two sets of universities embraced and adopted during the pandemic was another form of social distancing and safety protocol that frequently characterises the messaging around COVID-19 non-pharmaceutical prevention measures. However, even though emergency remote/online instruction was adopted by one university in both university sets, this paper argues, in keeping with Murphy's (2020) above, that what all these universities pivoted to during the COVID-19 pandemic outbreak was emergency remote pedagogy, notwithstanding the nomenclature they assigned to their respective online delivery modes. That is, they did not voluntarily transition to online delivery; rather, the prevalent COVID-19 at the time, forced them to do so. In a different but related scenario, Sener (2010) contends that "an emergency response to a devastating natural or man-made hazard" (p. 9) serves as one of the instances of the adoption and growth of online higher education spawned by "the wildcard effect" (p. 9). Nonetheless, as argued earlier, embracing online pedagogy is not inherently a new normal as this pedagogy has always been there. This transitional online delivery enabled the universities in question to carry out their "school's out, but class's on" (Zhou, Li, Wu \& Zhou, 2020, p. 501) business continuity plans.

Viewed from a framing perspective, the four typologies of online delivery and their related permutations attributed to the two sets of universities constitute frames through which these universities perceived and constructed their transitional online delivery modes. While in their conventional sense frames are situationally and socially determined (Goffman, 1974; Mertala, 2019), in the case of the two sets of universities they are theorised as contextually and pedagogically determined. That is, the online delivery mode each university opted for and the specific nomenclature it employed to refer to that delivery mode was determined by its own institutional contextual conditions and its own pedagogical considerations. These two sets of factors are differentiators that determined and informed the type of online delivery mode to which each university pivoted and the name it assigned to it. Otherwise, it is unfathomable that any $\mathrm{HEl}$ can embrace and pivot to a given instructional mode during a health emergency and during a pandemic crisis without taking into account its contextual and pedagogical considerations. If it did, it would be risking its institutional and academic integrity.

Another aspect related to the framing paradigm espoused by this paper is that the typologies of online delivery together with their attendant permutations - imputed to the two sets of universities constitute multiple frames through which these universities perceived and construed their respective online delivery modes. This aspect is instantiated by the divergent and convergent names these institutions used to refer to their online delivery modes. That is, some used similar or overlapping online delivery names, while others employed dissimilar or divergent online delivery names (see Tables 5 and 7). Highlighting the notion of multiple frames Mertala (2019) contends that since such frames are layered, they enable individuals to apply several frames simultaneously in interpreting 
and acting in their own world. This means that frames vary from entity to entity and lead to reality to be multiply conceived. Again, this aspect is exemplified by the multiple names the two sets of universities used to refer to their online delivery modes. To this end, Pick (2003) argues that frames result in multiple conceptions of social reality.

In addition, Pick (2003) identifies three levels of framing: rhetorical, action and positional frames. The first level relates to the value system and the general interpretations within which a particular action occurs. The second level refers to an explicit commitment to a given course of action, while the third level is about a constellation of elements and contextual factors and interests of a stakeholder institution that inform individuals' interpretations of the issue at hand. These three levels intersect and overlap, but are indeterminate and incessantly changing. Concerning the two university sets, rhetorical frames are exemplified by an institutional value system within which each university opted to pivot to its preferred online delivery mode as reflected in its communiqué about both campus closure and online delivery transition (see Appendices A and B). Positional frames are embodied in each university's explicit commitment to executing and implementing its preferred online delivery mode. Action frames for these universities are exemplified by a matrix of contextual factors and institutional interests that underpin how these universities interpreted the challenge of pivoting to their respective online delivery modes after communiqués about their campus closures and online delivery transition were issued (see Tables 4 and 7; Appendices $\mathrm{A}$ and $\mathrm{B}$ ).

Furthermore, when the U.S. and South African universities transiently transitioned their classes to online delivery during the COVID-19 pandemic outbreak, they each adopted and utilised certain online tools and resources. For 63 of the 64 U.S. universities studied, the five most adopted and utilised tools were Zoom, Canvas, Blackboard (Collaborate), Panopto and Microsoft Teams, with video conferencing platforms and LMS platforms emerging as the two dominant platforms. Overall, Zoom was the most preferred tool for all these universities, except for one that did not identify the tools it used. To this end, Zoom seems to have morphed into the posterchild and flagship platform of teaching and learning during the COVID-19 pandemic (Lueth, 2020). Likewise, Kandri (2020) echoes the same sentiment when she points out that Zoom (together with Webex) has offered a lifeboat to many universities across the globe in the midst of the pandemic (also see Bary, 2020).

With reference to the online tools that 17 of the 21 South African universities embraced during the COVID-19 pandemic, the five most adopted and used tools were Blackboard (Collaborate), institutional LMSes, WhatsApp, Zoom and Moodle, with the first two tools as the joint most adopted, while LMS platforms and video conferencing platforms emerged as the dominant platforms. This means that the video conferencing platforms were the most adopted and the most dominant online tools common for the two sets of universities during this period. In this regard, Khagram (2020) opines that entities that have resisted change for many years have gone virtual overnight because of the coronavirus pandemic. He further maintains that in this unfolding pandemic scenario, video conferencing has emerged as a cardinal means of remote learning and co-working that blurs the boundaries between the digital, physical and biological spheres. In this way, he is of the view that video conferencing seems to be accelerating the fourth industrial revolution (4IR) (also see Javaid et al., 2020; Zhu \& Liu, 2020).

Overall, the dominant online tools such as Zoom, Blackboard (Collaborate) and institutional LMSes to which both sets of universities pivoted during this pandemic are, with the exception of Zoom, not new online delivery technologies. The same applies to the majority of tools such as Canvas, Google Hangouts/Meet, Panopto, Microsoft Office 365 and OneDrive (for given U.S. universities) and to tools such as WhatsApp, Moodle and Coursera (for certain South African universities). This means that during the COVID-19 pandemic outbreak, 63 of the 64 U.S. universities and 17 of the 21 South African universities pivoted to commonly known online delivery 
tools. If this is the case, then, this implies that these universities did not readily and fully embrace and pivot to the flagship technologies - e.g., artificial intelligence, robotics, automation, the Internet of Things, augmented and virtual reality, blockchain, cloud computing, drones, and 3D printing (see Chaka, 2019, Pereira \& Romero, 2017; Weller, 2020) - constituting the 4IR. If anything, they only embraced low-tech versions of the 4IR technologies such as video-conferencing, social media technologies, and cloud computing. Examples of the latter are cloud computing storage tools like OneDrive and Google Drive. This response of embracing familiar technologies during a pandemic or emergency situation resonates with the intuitive and pedagogic caution that a crisis or emergency moment is not an opportune moment for experimenting with "fancy new tools" (Dill et al., 2020, p. 7). That is, it is a moment for resorting to the boring, mundane (Weller, 2020; also see Hodges et al., 2020), but tried and tested tools.

In respect of stance, by embracing and adopting the specific online tools during the COVID-19 pandemic, the universities in question in both sets took a stance in relation to these tools. For instance, in the case of U.S. universities, one university utilised only one tool, five universities used two tools, while some utilised more than two tools, with the others employing a suite of tools. In the case of South Africa universities, seven universities used a single tool, whereas six universities employed more than two tools. All of this reflects an institutional stance each university adopted pertaining to online tool(s) to which it wanted to pivot during this pandemic period given its resources capacity. This online delivery technologies adoption by the universities concerned should be seen against the backdrop of these universities' social distancing strategy. From a framing perspective, the online tools these universities adopted during this period, as is the case with their online delivery modes, were determined by their own institutional contextual conditions and their own pedagogical considerations. Again, rhetorical frames for the two sets of universities are embodied by an institutional value system within which each university chose to pivot to its preferred online tool(s) (see Tables 6 and 7). Similarly, positional frames are embodied in each university's explicit commitment to deploying its preferred online tool(s), while action frames for these universities are represented by a matrix of contextual factors and institutional desires that underpin how these universities construed the challenge of pivoting to their respective online tool(s).

Lastly, 62 of the 64 U.S. universities provided help, tips, suggestions and guidelines for faculty and students, or for either faculty or students. Some of these universities offered resources, workshops, trainings and webinars to faculty for pivoting to online instruction, while 17 universities provided student offers or student concessions ranging from emergency funding to (loaner) laptops to free access to digital publications. Pertaining to South African universities, 7 of them offered guidelines or orientation to staff. Two of these provided a webinar and a training apiece. Additionally, 11 universities offered zero-rated data and designated zero-rated institutional websites to students. This means that more (97\%) of U.S. universities offered help, tips, suggestions, or guidelines for online instruction pivoting to their faculty and students (or to either of these stakeholders) than their South African counterparts (33\%). However, more (52\%) of South African universities provided student offers/concessions than their U.S. counterparts (26\%), even though the quality of these offers was not the same. In this regard, the percentage of the 64 U.S. universities that offered suggestions to faculty for utilising technology for alternative course delivery is much higher than that of the 50 U.S. universities that did so to their faculty during the H1N1 flu pandemic as reported by Meyer and Wilson's (2011) study. In the latter study, only $32 \%$ of the 50 universities provided suggestions to their faculty for pivoting their course delivery to technology.

\section{Limitations and Future Research}


This study was an online review of how selected U.S. and South Africa universities responded to the COVID-19 pandemic regarding their teaching and learning activities, and of the types of online tools and resources they embraced during this period. Most online review studies, especially those that are desktop-based, are often prone to misrepresentations and inaccuracies. This is particularly so as some of the documents and resources posted on websites and on university portals are outdated. As such, any information or any data harvested from such documents or from such resources is not likely to be a true representation of the actual state-of-art of some of these universities in their real-world scenarios. However, during the data collection period, all the websites and the portals of the different universities were regularly visited with an eye to locating updated information and communiqués. Besides, an online desktop-based study was the only available logical option during this public health emergency period, given the prevalent global social distancing requirement and the campus closures that ensued.

Another point worth mentioning is that the nature of the study and the period during which it was conducted were such that they could not allow for the verification of the statements and commitments embodied in the communiques and in the other related documents posted on the websites and on the portals of the different universities with the real-world practices of these universities. To this end, the study did not explore whether or not the respective universities carried out what they claimed they would carry out on their websites and on their portals. Elsewhere, documents such as communiques, announcements, notices, addresses and newspaper articles posted on websites or on portals are regarded as grey literature and, as such, they are perceived to be less reliable as they are not peer-reviewed. Nonetheless, in the case of this study, these documents served as critical sources of data.

\section{Implications And Conclusions}

As mentioned earlier on, the purpose of this online review study was to review how certain U.S. and South African universities pivoted to online course delivery and used online tools and resources as one of their collective responses to continuing their teaching and learning activities during the COVID-19 pandemic. In the main, all of the U.S and South African universities (64 and 21, respectively) investigated pivoted to online classes and temporarily relinquished their in-person, campus-based classes. The major reason for their doing so was to embrace and implement social distancing as one of the non-pharmaceutical interventions recommended for reducing person-toperson viral infection rates during COVID-19. Thus, during this crisis moment, these universities resorted to shortterm emergency remote pedagogy as a solace to ensure and salvage their teaching and learning continuity, and as a means to comply with social distancing. This implies that emergency remote online pedagogy serves as a logical solace for salvaging academic business continuity not only for the universities investigated, but also for the other HEls during pandemic and emergency crises characterised by "punctuational changes" (Could \& Eldredge, 1977, p. 115) or by "punctuated equilibria" (p. 119) such as the currently evolving COVID-29 pandemic.

Additionally, all of these universities seem to have temporarily opted for a strong form of social distancing since they implemented wholesale closures of their campuses at the outbreak of the COVID-19 pandemic. In this context, the current paper has argued that the social distancing these two sets of universities implemented entailed geometric and metaphoric social distancing. Above all, the paper has contended that by adopting social distancing, these universities also adopted and displayed an act of stance-taking. This, therefore, implies that social distancing entailed taking a stance on the part of these universities informed by a specific university's teaching and learning continuity plan.

Page 20/46 
Moreover, when the reviewed U.S. and South African universities transiently transitioned their classes to online delivery during the COVID-19 outbreak, four online delivery typologies emerged, which had multiple permutations. Three of these four typologies were shared in common by the two sets of universities: online instruction, remote instruction and emergency instruction. Remote instruction had the most permutations, while online instruction had the highest mention frequency among U.S. universities. Pertaining to South African universities, online instruction had the most permutations and the highest mention frequency. To this end, the paper has argued that these typologies and their attendant permutations reflect a specific stance each university in each set took vis-à-vis the name it attached to its online class delivery mode. Besides, the paper has postulated, in keeping with Murphy's view (2020, p. 9) of "the normalization of emergency eLearning" (p. 9) during COVID-19, that the reviewed sets of universities normalised emergency remote online pedagogy during their COVID-19 transitional online delivery period. Again, the four online delivery typologies (together with associated permutations) imputed to the two sets of universities constitute frames through which these universities perceived and constructed their transitional online delivery modes.

Furthermore, when both U.S. and South African universities temporarily pivoted their classes to online delivery during the COVID-19 pandemic outbreak, they embraced and adopted certain online tools and resources more than the others. For instance, Zoom, Canvas, Blackboard (Collaborate), Panopto and Microsoft Teams were the five most embraced online tools by 63 of the 64 U.S. universities. Of these, Zoom was the most preferred tool, with video conferencing and LMS platforms emerging as the two dominant platforms. As regards the 21 South African universities, Blackboard (Collaborate), institutional LMSes, WhatsApp, Zoom and Moodle were the five most embraced online tools by 17 of the 21 universities. Here the first two tools were the joint most adopted, with both LMS and video conferencing platforms emerging as the two dominant platforms. To this end, Zoom, Blackboard (Collaborate) and institutional LMSes were the three common tools to which both sets of universities pivoted during the pandemic. Overall, when all the online tools are pulled together, it emerges that during the COVID-19 pandemic outbreak, the two sets of universities transitioned to the tried and tested tools with no temptation to embrace new and fancy tools. Most importantly, the paper has argued that the two sets of universities only embraced low-tech versions of the 4IR technologies such as video-conferencing, social media technologies, and cloud computing. All of this reflects the stance these universities took vis-à-vis the online tools and resources that resonated with their contextual circumstances and with their institutional and pedagogical imperatives.

With reference to help and support about online pivoting, more (97\%) of U.S. universities offered help, tips, suggestions, or guidelines for online instruction pivoting to their faculty and students (or to either of these stakeholders) than their South African counterparts (33\%). Nonetheless, more (52\%) of South African universities provided student offers/concessions than their U.S. counterparts $(26 \%)$, even though such offers were not qualitatively the same.

Finally, in spite of the limitations mentioned in the preceding section, some of the findings of this study stand to benefit future online studies conducted during the outbreaks of pandemics, especially the one such as the COVID19 pandemic that necessitated social distancing and campus closures as some of the non-pharmaceutical intervention measures. The other point to highlight about this study is that it is replicable, even though its findings may not necessarily be generalisable as the contexts under which pandemics occur generally vary. For example, the response of the universities explored in this study to pivot their academic activities to online instruction as one of the strategies to salvage and academic business continuity during the COVID-19 warrants a closer and further investigation. This is particularly so as it is necessary to monitor whether online instruction is not likely to become 
a possible option for HIEs to embrace as a post-pandemic pedagogy, or in any future pandemics or emergencies. Most importantly, it will be interesting to watch how, going forward, HIEs can embrace the different types of 4 IR technologies as part of their overall online pedagogy beyond embracing just low-tech versions of 4IR technologies as has been the case in the current study.

\section{Declarations}

\section{Acknowledgements}

The author would like to thank the two other raters who helped him rate the datasets.

\section{Funding}

There was no funding for this research project.

\section{Availability of data and materials}

The data sources are available from Tables 4 and 7, from Appendices A and B, and from respective universities' websites and portals.

\section{Competing interests: The author declares no competing interests.}

\section{References}

Alaimo, S. (2020). College Connection: The difference between 'Public Ivy' and Ivy League. Retrieved from https://www.mycentraljersey.com/story/news/education/college/2020/01/31/college-difference-between-publicivy-and-ivy-league/4590771002/

Amos, J. R., \& Howard, C. (2020). How social distancing brought us closer as a BME community. Annals of Biomedical Engineering, 48(5), 1443-1444. https://doi.org/10.1007/s10439-020-02501-4

Arksey, H., \& O'Malley. L. (2005). Scoping studies: Towards a methodological framework. International Journal of Social Research Methodology: Theory \& Practice, 8(1), 19-32.

Association of Public \& Land Grant Universities. (2020) Public University Communications on COVID-19. Retrieved from https://www.aplu.org/news-and-media/communications-resources/coronavirus/

Aziz, S. (2020). Why 'physical distancing' is better than 'social distancing'. Retrieved from https://www.aljazeera.com/news/2020/03/physical-distancing-social-distancing-2 $\quad 00330143325112 . h t m l$

Fleiss, J. (1971). Measuring nominal scale agreement among many raters. Psychological Bulletin, 76, $378-381$.

Bary, E. (2020). 'This is online education's moment' as colleges close during coronavirus pandemic. Retrieved from https://www.marketwatch.com/story/this-is-online-educations-moment-as-colleges-close-during-coronaviruspandemic-2020-03-17 
Basilaia, G, \& Kvavadze, D. (2020). Transition to online education in schools during a SARS-CoV-2 coronavirus (COVID-19) pandemic in Georgia. Pedagogical Research, 5(4), em0060. https://doi.org/10.29333/pr/7937

Bates, T. (2020). Advice to those about to teach online because of the corona-virus. Retrieved from https://www.tonybates.ca/2020/03/09/advice-to-those-about-to-teach-online-because-of-the-corona-virus/

Bates, A. W. (2015). Teaching in a digital age: Guidelines for designing teaching and learning. Vancouver BC: Tony Bates Associates Ltd.

Beller, E., Glasziou, P. P., Altman, D. G., Hopewell, S., Bastian, H., Chalmers, I., Gøtzsch, P. C., et al. (2013). PRISMA for abstracts: Reporting systematic reviews in journal and conference abstracts. PLOS Medicine, 10(4), e1001419. doi:10.1371/journal.pmed.1001419

Blackboard Support. (1998). Educational benefits of online learning. Retrieved from http://blackboardsupport.calpoly.edu/content/faculty/handouts/Ben_Online.pdf

Blackburn, S. (2020). Updated: 48 free higher ed resources during coronavirus pandemic. Retrieved from https://universitybusiness.com/free-college-management-software-faculty-resources-coronavirus-covid-19/

Blumenstyk, G. (2020). Why coronavirus looks like a "black swan” moment for higher education. The Chronicle. Retrieved from https://www.chronicle.com/article/Why-Coronavirus-Looks-Like-a/248219.

Booth, A. (2016). Searching for qualitative research for inclusion in systematic reviews: A structured methodological review. Systematic Reviews, 5(74), 1-23. doi 10.1186/s13643-016-0249-x

Burki, T. K. (2020). COVID-19: consequences for higher education. The Lancet Oncology, 758, 21, https://doi.org/10.1016/S1470-2045(20)30287-4

Burla, L., Knierim, B., Liewald, J. B. K., Duetz, M., \& Abel, T. (2008). From text to codings: Intercoder reliability assessment in qualitative content analysis. Nursing Research, 57(2), 113-117.

Caffee, A. (2020). 2020 List of Ivy League schools, ranked and reviewed. Retrieved from https://www.niche.com/blog/list-of-ivy-league-schools-ranked-and-reviewed/

Castleberry, A., \& Nolen, A. (2018). Thematic analysis of qualitative research data: Is it as easy as it sounds? Currents in Pharmacy Teaching and Learning, 10, 807-815. https://doi.org/10.1016/j.cptl.2018.03.019

Chaka, C. (2019). Skills, competencies and literacies attributed to 4IR/Industry 4.0: Scoping review. IFLA Journal, XX(X), 1-33. doi: 10.1177/0340035219896376

Chaka, C. \& Nkhobo, T. (2019). Online module login data as a proxy measure of student engagement: The case of myUnisa, MoyaMA, Flipgrid, and Gephi at an ODeL institution in South Africa. International Journal of Educational Technology in Higher Education, 16(1), article \#38.

Chaka, C., Lephalala, M., \& Ngesi, N. (2017). English studies: Decolonisation, deparochialising knowledge and the null curriculum. Perspectives in Education, 35(2), 208-229. http://dx.doi.org/10.18820/2519593X/pie.v35i2.16 
Chick, R. C., Clifton, G. T., Peace, K. M., Propper, B. W., Hale, D. F., Alseidi, A. A., Vreeland, T. J. (2020). Using technology to maintain the education of residents during the COVID-19 pandemic. Journal of Surgical Education. https://doi.org/10.1016/j.jsurg.2020.03.018

Cicchetti, D. V. (1994). Guidelines, criteria, and rules of thumb for evaluating normed and standardized assessment instruments in psychology. Psychological Assessment, 6, 284-90.

Cohen, J. (1960). A coefficient of agreement for nominal scales. Educational and Psychological Measurement, 20(1), 37-46. https://doi.org/10.1177/001316446002000104

Cornock, M. (2020). Scaling up online learning during the coronavirus (Covid-19) pandemic. Retrieved from https://mattcornock.co.uk/technology-enhanced-learning/scaling-up-online-learning-during-the-coronavirus-covid19-pandemic/

Crawford, J., Butler-Henderson, K., Rudolph, J., Glowatz, M., Malkawi, B., Burton, R., Magni, P., et al. (2020). COVID19: 20 countries' higher education intra-period digital pedagogy responses. Journal of Applied Learning and Teaching, 1-40.

Darby, F. (2020). How to be a better online teacher. The Chronicle of Higher Education, 11-23. Retrieved from https://connect.chronicle.com/CS-WC-2020-CoronavirusFreeReport_LP-SocialTraffic.html

Darling-Hammond, L. (2020). Learning in the time of COVID-19. Retrieved from https://www.forbes.com/sites/lindadarlinghammond/2020/03/19/learning-in-the-time-of-covid19/\#54dd08457203

debuglies.com. (2020). Intermittent social distancing may have to be employed to reduce the burden on the health care system as a result of COVID-19. Retrieved from http://debuglies.com/2020/03/29/intermittent-socialdistancing-may-ha

Designing Digitally. (/2019). Common online learning terms and definitions Retrieved from https://www.designingdigitally.com/blog/common-online-learning-terms-definitions

Dill, E., Fischer, K., Mcmurtrie, B., \& Supiano, B. (2020). As coronavirus spreads, moving classes online is the first step. What's next? The Chronicle of Higher Education, 4-7. Retrieved from https://connect.chronicle.com/CS-WC2020-CoronavirusFreeReport_LP-SocialTraffic.html

Dijkers, M. (2015). What is a scoping review. KT Update, 4(1), 1-5.

Du Bois, J. (2007). The stance triangle. In R. Englebretson (Ed), Stancetaking in discourse: subjectivity, evaluation, interaction, (pp. 139-182). Amsterdam/Philadelphia: Benjamins.

Doung, V., Luo, J., Pham, P., Yang, T., \& Wang, T. (2020). The ivory tower lost: How college students respond differently than the general public to the COVID-19 pandemic. arXiv:2004.09968v1

Elsevier. (2020). Novel Coronavirus Information Center. Retrieved from https://www.elsevier.com/connect/coronavirus-information-center 
Erlingsson, C., \& Brysiewicz, P. (2017). A hands-on guide to doing content analysis. African Journal of Emergency Medicine, 7, 93-99. http://dx.doi.org/10.1016/j.afjem.2017.08.001

Ethington, P. J. (1997). The intellectual construction of "social distance": Toward a recovery of Georg Simmel's social geometry. Cybergeo: European Journal of Geography, 1-22. doi: 10.4000/cybergeo.227

European Commission. (2020). Coronavirus: online learning resources. Retrieved from https://ec.europa.eu/education/resources-and-tools/coronavirus-online-learning-resources_en

Everitt, B. (1996). Making sense of statistics in psychology: A second-level course. Oxford, UK: Oxford University Press.

Fernandez, A. A., \& Shaw, G. P. (2020). Academic leadership in a time of crisis: The coronavirus and COVID-19. Journal of Leadership Studies, 14(1). doi:10.1002/jls.21684

Financial Times. (2020). Remote teaching becomes vital during coronavirus outbreak. Retrieved from https://www.ft.com/content/bae2a4b2-5fa1-11ea-b0ab-339c2307bcd4

FutureLearn. (2020). COVID-19: The best resources for online teaching during coronavirus. Retrieved from https://www.futurelearn.com/info/blog/resources-for-online-teaching-during-coronavirus

Gannon, K. (2020). Lessons from moving a face-to-face course online. The Chronicle of Higher Education, 24-27. Retrieved from https://connect.chronicle.com/CS-WC-2020-CoronavirusFreeReport_LP-SocialTraffic.html

Gardner, J. M., Willem, L., van der Wijngaart, W., Kamerlin, S. C. L., Brusselaers, N., \& Kasson, P. (2020). Intervention strategies against COVID-19 and their estimated impact on Swedish healthcare capacity. medRxiv, 1-33.

10.1101/2020.04.11.20062133

Germann, T. C., Gao, H., Gambhir, M., Plummer, A., Biggerstaff, M., Reed, C., \& Uzicanin, (2019). School dismissal as a pandemic influenza response: When, where and for how long? Epidemics, 28, 100348.

doi:10.1016/j.epidem.2019.100348

Gould, S. J., \& Eldredge, N. (1977). Punctuated equilibria: The tempo and mode of evolution reconsidered. Paleobiology, 3(2), 115-151. Retrieved from http://www.johnboccio.com/courses/SOC26/BakSneppan/07_Gould.pdf

Grajek, S. (2020). Educause COVID-19 QuickPoll results: Help for students. Retrieved from https://er.educause.edu/blogs/2020/4/educause-covid-19-quickpoll-results-help-for-students

Hayati, R., Bastani, P., Kabir, M. J., Kavosi, Z., \& Sobhani, G. (2018). Scoping literature review on the basic health benefit package and its determinant criteria. Globalization and Health, 14(26), 1-7.

https://doi.org/10.1186/s12992-018-0345-x

Hodges, C., Moore, S., Lockee, B., Trust, T., \& Bond, A. (2020). The difference between emergency remote teaching and online learning. Retrieved from https://er.educause.edu/articles/2020/3/the-difference-between-emergencyremote-teaching-and-online-learning 
Houlden, S., \& Veletsianos, G. (2020). Coronavirus pushes universities to switch to online classes - but are they ready? Retrieved from http://theconversation.com/coronavirus-pushes-universities-to-switch-to-online-classes-butare-they-ready-132728

Hsieh, H-F., \& Shannon, s. E. (2005). Three approaches to qualitative content analysis. Qualitative Health Research, 15(9), 1277-1288. doi: 10.1177/1049732305276687

Huang, R. H., Liu, D. J., Tlili, A., Yang, J. F., Wang, H. H., et al. (2020). Handbook on facilitating flexible learning during educational disruption: The Chinese experience in maintaining undisrupted learning in COVID-19 outbreak. Beijing: Smart Learning Institute of Beijing Normal University.

Hutton, B., Salanti, G., Caldwell, D. M., Chaimani, A., Schmid, C. H., Cameron, C., loannidis, J. P. A., et al. (2015). The PRISMA extension statement for reporting of systematic reviews incorporating network meta-analyses of health care interventions: Checklist and explanations. Annals of Internal Medicine, 162, 777-784. doi:10.7326/M14-2385

Hyland, K. (1996). Talking to the academy: Forms of hedging in science research articles. Written Communication, $13,251-281$.

Hyland, K. (2005). Stance and engagement: A model of interaction in academic discourse. Discourse Studies, 7(2), 173-192.

International Association for K-12 Online Learning. (2011). The online learning definitions project. Retrieved from http://dese.ade.arkansas.gov/public/userfiles/Learning_Services/Digital_Learning/iNACOL_DefinitionsProject.pdf.

International Baccalaureate Organization. (2020). Online learning, teaching and education continuity planning for schools. Retrieved from https://www.ibo.org/globalassets/news-assets/coronavirus/online-learning-continuityplanning-en.pdf

Jalali, H. (2017). Reflection of stance through it bundles in applied linguistics. Ampersand, 4,30-39. http://dx.doi.org/10.1016/j.amper.2017.06.001

Jandrić, P. (2020). Postdigital research in the time of Covid-19. Postdigital Science and Education, 2, $233-238$. https://doi.org/10.1007/s42438-020-00113-8

Javaid, M., Haleem, A., Vaishya, R., Bahl, S., Suman, R., \& Vaish, A. (2020). Industry 4.0 technologies and their applications in fighting COVID-19 pandemic. Diabetes \& Metabolic Syndrome: Clinical Research \& Reviews, 14, 419-422. https://doi.org/10.1016/j.dsx.2020.04.032

Johnston, K. (1995). A methodology for frame analysis: From discourse to cognitive schemata. In H. Johnston \& B. Klandermans (Eds), Social movements and culture (pp. 217-246). Minneapolis: University of Minnesota Press.

Jowsey, T., Foster, G., Cooper-loelu, P., \& Jacobs, S. (2020). Blended learning via distance in pre-registration nursing education: A scoping review. Nurse Education in Practice, 4, 102775. https://doi.org/10.1016/j.nepr.2020.102775

Kahoot!. (2020). Kahoot! offers free distance learning tools during the coronavirus outbreak. Retrieved from https://kahoot.com/coronavirus-remote-offer 
Kamenetz, A. (2020). 'Panic-gogy': Teaching online classes during the coronavirus pandemic. Retrieved from https://www.npr.org/2020/03/19/817885991/panic-gogy-teaching-online-classes-during-the-coronaviruspandemic

Kandri, S-E. (2020). How COVID-19 is driving a long-overdue revolution in education. Retrieved from https://www.weforum.org/agenda/2020/05/how-covid-19-is-sparking-a-revolution-in-higher-education/

Khagram, S. (2020). How the coronavirus pandemic accelerates the 4th Industrial Revolution. Retrieved from https://www.newswise.com/coronavirus/how-coronavirus-pandemic-accelerates-the-technology-of-the-4thindustrial-revolution-https-eiuperspectives-economist-comfinancial-serviceswhy-coronavirus-will-accelerate-fourthindustrial-revolution-4ir/?article_id=730580

Kissler, S., Tedijanto, C., Lipsitch, M., \&. Grad, Y. H. (March, 2020). Social distancing strategies for curbing the COVID-19 epidemic. medRxiv. https://doi.org/10.1101/2020.03.22.20041079

Kohlbacher, F. (2006). The use of qualitative content analysis in case study research. Forum Qualitative Sozialforschung/Forum: Qualitative Social Research, 7(1), Article \#21.

Koon, A. D., Hawkins, B., \& Mayhew, S. H. (2016). Framing and the health policy process: A scoping review. Health Policy and Planning, 31, 801-816. doi: 10.1093/heapol/czv12

Lai, C-C., Liu, Y. H, Wang, C-Y., Wang, Y-H., Hsueh, S-C., Yen, M-Y, Ko, W-C, et al. (2020). Asymptomatic carrier state, acute respiratory disease, and pneumonia due to severe acute respiratory syndrome coronavirus 2 (SARS-CoV-2): Facts and myths. Journal of Microbiology, Immunology and Infection, xxx (xxxx) xxx.

https://doi.org/10.1016/j.jmii.2020.02.012

Lederman, D. (2020). The state of online education, before coronavirus. Retrieved from https://www.insidehighered.com/news/2020/03/25/survey-gauges-state-online-education-landscape-precoronavirus

Lin, W., Chen, Y., Shi, S., Liang, J., Huang, H., Li, L., Cai, L., et al. (2020). Thoughts on higher medical education under major public health emergencies: Thinking ahead after covid-19 outbreak. medRxiv, 1-23. https://doi.org/10.1101/2020.04.06.20053918

Lueth, K. L. (2020). The impact of Covid-19 on the Internet of Things - now and beyond the Great Lockdown. Retrieved from https://iot-analytics.com/the-impact-of-covid-19-on-the-internet-of-things-part-2/

Mahase, E. (2020). China coronavirus: WHO declares international emergency as death toll exceeds 200. British Medical Journal, 368:m408.

Manderson, L., \& Levine, S. (2020). COVID-19, risk, fear, and fall-out. Medical Anthropology. https://doi.org/10.1080/01459740.2020.1746301

Maragakis, L. L. (2020). Coronavirus, social and physical distancing and self-quarantine. Retrieved from https://www.hopkinsmedicine.org/health/conditions-and-diseases/coronavirus/coronavirus-social-distancingand-self-quarantine 
Means, B., Bakia, M., \& Murphy, R. (2014). Learning online: What research tells us about whether, when and how. New York: Routledge.

Means, B., Toyama, Y., Murphy, R., Bakia, M., \& Jones, K. (2010). Evaluation of evidence-based practices in online learning a meta-analysis and review of online learning studies. Retrieved from

https://www2.ed.gov/rschstat/eval/tech/evidence-based-practices/finalreport.pdf

Meng, L., Hua, F., \& Bian, Z. (2020). Coronavirus disease 2019 (COVID-19): Emerging and future challenges for dental and oral medicine. Journal of Dental Research, 00(0), 1-7. https://doi.org/10.1177/002203452091424

Mertala, P. (2019). Digital technologies in early childhood education - A frame analysis of preservice teachers' perceptions. Early Child Development and Care, 189(8), 1228-1241.

https://doi.org/10.1080/03004430.2017.1372756.

Meyer, K. A., \& Wilson, J. L. (2011). The role of online learning in the emergency plans of flagship institutions. Online Journal of Distance Learning Administration, 4(1). Retrieved from https://www.westga.edu/ distance/ojdla/spring141/meyer_wilson141.html.

Mian, A., \& Khan, S. (2020). Medical education during pandemics: A UK perspective. BMC Medicine, 18(100). https://doi.org/10.1186/s12916-020-01577-y

Miller, M. D. (2020). Going online in a hurry: What to do and where to start. The Chronicle of Higher Education, 810. Retrieved from https://connect.chronicle.com/CS-WC-2020-CoronavirusFreeReport_LP-SocialTraffic.html

Morris, D., Plotkin, J. B., Rossine, F. W., \& Levin, S. (2020). Optimal, near-optimal, and robust epidemic control. Retrieved from https://osf.io/9gr7q/download

Mukherjee, M. (2020). What coronavirus outbreak means for global higher education. Retrieved from http://dspace.jgu.edu.in:8080/jspui/handle/10739/3391

Murphy, M. P. A. (2020). COVID-19 and emergency eLearning: Consequences of the securitization of higher education for post-pandemic pedagogy. Contemporary Security Policy, 1-15. https://doi.org/10.1080/13523260.2020.1761749

Najmabadi, S. (2020). Texas universities ramp up online teaching amid coronavirus pandemic. Retrieved from https://www.texastribune.org/2020/03/18/texas-universities-ramp-online-teaching/

Ng, Y-M, \& Peggy, P. L. (2020). Coronavirus disease (COVID-19) prevention: Virtual classroom education for hand hygiene. Nurse Education in Practice. doi: https://doi.org/10.1016/j.nepr.2020.102782.

Nicola, M., O’Neill, N., Sohrabi, C., Khan, M., Agha, M., \& Agha, R. (2020). Evidence based management guideline for the COVID-19 pandemic - Review article. International Journal of Surgery.

https://doi.org/10.1016/j.ijsu.2020.04.001.

Nurse Key. (2017). Finding and reviewing research evidence in the literature. Retrieved from https://nursekey.com/finding-and-reviewing-research-evidence-in-the-literature/ 
Omrow, D. A. (2018). It is not easy being green: A critical discourse and frame analysis of environmental advocacy on American television. Journal of Media and Communication Studies, 10(3), 14-24. doi:

10.5897/JMCS2018.0609

Palvia, S., Aeron, P., Gupta, P., Mahapatra,D., Parida, R., Rosner, R., \& Sindhi, S. (2018). Online education: Worldwide status, challenges, trends, and implications. Journal of Global Information Technology Management, 21(4), 233241. doi: 10.1080/1097198X.2018.1542262

Pereira, A.C., \& Romero, F. (2017). A review of the meanings and the implications of the Industry 4.0 concept. Procedia Manufacturing, 13, 1206-1214.

Perrotta, C. (2020). Coronavirus quarantine could spark an online learning boom. Retrieved from http://theconversation.com/coronavirus-quarantine-could-spark-an-online-learning-boom-132180

Peters, M. A., Jandrić, P., \& McLaren, P. (2020): Viral modernity? Epidemics, infodemics, and the 'bioinformational' paradigm. Educational Philosophy and Theory, doi: 10.1080/00131857.2020.1744226

Pick, D. (2003). Framing and frame shifting in a higher education merger. Tertiary Education and Management, 9(4), 299-316. doi: 10.1080/13583883.2003.9967111

Poirier, T., \& Behnen, E. (2014). Where and how to search for evidence in the education literature: The WHEEL. American Journal of Pharmaceutical Education, 78(4), article \#70.

Potter, K. (2019). What are Ivy League universities and why should I care? Retrieved from https://www.mastersportal.com/articles/1958/what-are-ivy-league-universities-and-why-should-i-care.html

Powell, A. (2020). On-again, off-again looks to be best social-distancing option. Retrieved from https://news.harvard.edu/gazette/story/2020/03/how-to-prevent-overwhelming-hospitals-and-build-immunity/

Ramsey, C. B. (2020). Human agency and infection rates: implications for social distancing during epidemics. medRxiv preprint. https://doi.org/10.1101/2020.04.11.20062042

Ray, T. (2020). Harvard researchers: Social distancing during COVID-19 may have to be turned on and off like a spigot. Retrieved from https://www.zdnet.com/article/harvard-researchers-social-distancing-during-covid-19-mayhave-to-be-turned-on-and-off-like-a-spigot/

Sahu, P. (2020). Closure of universities due to coronavirus disease 2019 (COVID-19): Impact on education and mental health of students and academic staff. Cureus, 12(4), e7541. doi:10.7759/cureus.7541

Sampathkumar, M., \& Shwayder, M. Coronavirus exposes digital disparities between students as learning goes online. Retrieved from https://www.digitaltrends.com/news/coronavirus-university-online-classes-disparities/

Schäfer, M. S., \& O'Neill, S. (2017). Frame analysis in climate change communication. Oxford research encyclopedia of climate science. doi: 10.1093/acrefore/9780190228620.013.487

Schaffhauser, D. (2020). Free and discounted ed tech tools for online learning during the coronavirus pandemic. Retrieved from https://campustechnology.com/articles/2020/03/16/free-and-discounted-ed-tech-tools-for-onlinelearning-during-the-coronavirus-pandemic.aspx 
Sener, J. (2010). Why online education will attain full scale. Journal of Asynchronous Learning Networks, 14(4), 3-16. https://eric.ed.gov/?id=EJ909907

Singh, V., \& Thurman, A. (2019). How many ways can we define online learning? A systematic literature review of definitions of online learning (1988-2018). American Journal of Distance Education, 33(4), 289-306. https://doi.org/10.1080/08923647.2019.1663082.

Smalley, A. (2020). Higher education responses to coronavirus (COVID-19). Retrieved from https://www.ncsl.org/research/education/higher-education-responses-to-coronavirus-covid-19.aspx

Soccolich, A. (2020). 111 Free tools to help you through the coronavirus pandemic. Retrieved from https://www.entrepreneur.com/article/347840

Sohrabi, C., Alsafi, Z., O’Neill, N., Khan, M., Kerwan, A., Al-Jabir, A., losifidis, C., et al. (2020). World Health Organization declares global emergency: A review of the 2019 novel coronavirus (COVID-19). International Journal of Surgery, 76, 71-76. https://doi.org/10.1016/j.ijsu.2020.02.034

Stanford, D. (2020). Remote teaching resources for business continuity. Retrieved from https://docs.google.com/spreadsheets/d/1VT9oiNYPyiEsGHBoDKIwLIWAsWP58sGV7A3oluEUG3k/htmlview fbclid=IwAR3JQFp0MDOD9_t0I5AEzF7NbNoScYhCF6I5KkBREwDuxdiJoPOfGijxflg\&urp=gmail_link

Surma, T. \& Kirschner, P. A. (2020). Technology enhanced distance learning should not forget how learning happens. Computers in Human Behavior, 110, 106390. https://doi.org/10.1016/j.chb.2020.106390

Taha, M. H., Abdall, M. E., Wadi, M., \& Khalafalla, H. (2020). Curriculum delivery in medical education during an emergency: A guide based on the responses to the COVID-19 pandemic. MedEdPublish. https://doi.org/10.15694/mep.2020.000069.1

The Chronicle of Higher Education. (2020). Moving online now: How to keep teaching during coronavirus. The Chronicle of Higher Education, 1-3. Retrieved from https://connect.chronicle.com/CS-WC-2020CoronavirusFreeReport_LP-SocialTraffic.html

The University of Arizona Libraries. (2020). Open access during the COVID-19 outbreak. Retrieved from https://libguides.library.arizona.edu/openaccess/oa-covid19

Trust, T., \& Whalen, J. (2020). Should teachers be trained in emergency remote teaching? Lessons learned from the COVID-19 pandemic. Journal of Technology and Teacher Education, 28(2), 189-199.

Tutton, M. (2020). Shift to online learning due to COVID-19 requires rethink of teaching: Experts. Retrieved from https://globalnews.ca/news/6685848/shift-to-online-learning-due-to-covid-19-requires-rethink-of-teaching-experts

Uscher-Pines, L., Schwartz, H. L., Ahmed, F., Zheteyeva, Y., Meza, E., Baker, G., \& Uzicanin, A. (2018). School practices to promote social distancing in K-12 schools: Review of influenza pandemic policies and practices. $B M C$ Public Health, 18, 406. https://doi.org/10.1186/s12889-018-5302-3

Valdez, L. D., Macri, P. A., \& Braunstein, L. A. (2012). Intermittent social distancing strategy for epidemic control. Physical Review, E 85. doi: 10.1103/PhysRevE.85.036108 
Van, D., McLaws, M-L., Crimmins, J., Maclntyre, C. R., \& Sealle, H. (2010). University life and pandemic influenza: Attitudes and intended behaviour of staff and students towards pandemic (H1N1) 2009. BCM Public Health, 10(130), 1-9. http://www.biomedcentral.com/1471-2458/10/130

Van Bavel, J. J., Baicker, K., Boggio, P. S., Capraro, V., Cichocka, A., Cikara, M., Crockett, J., et al. Using social and behavioural science to support COVID-19 pandemic response. Nature Human Behaviour, 4, 460-471. https://doi.org/10.1038/s41562-020-0884-z

Vandergriff, I. (2012). Taking a stance on stance: Metastancing as legitimation. Critical Approaches to Discourse Analysis across Disciplines, 6(1), 53-75.

Vellingiri, B., Jayaramayya, K., lyer, M., Narayanasamy, A., Govindasamy, V., Giridharan, B., Ganesan, S., et al., (2020). COVID-19: A promising cure for the global panic. Science of the Total Environment, 725, 138277. https://doi.org/10.1016/j.scitotenv.2020.138277

Viner, R. M., Russell, S. J., Croker, H., Packer, J., Ward, J., Stansfield, C., Mytton, O., et al. (2020). School closure and management practices during coronavirus outbreaks including COVID-19: A rapid systematic review. Lancet Child Adolescent Health, 1-8. https://doi.org/10.1016/S2352-4642(20)30095-X

Ventriglio, A., Watson, C., \& Bhugra, D. (2020). Pandemics, panic and prevention: Stages in the life of COVID-19 pandemic. International Journal of Social Psychiatry, 1-2. doi: 10.1177/0020764020924449

Walker, P. G. T., Whittaker, C., Watson, O., Baguelin, M., Ainslie, K. E. C., Bhatia, S., Bhatt, S., et al. (2020). The global impact of COVID-19 and strategies for mitigation and suppression. Imperial College London.

https://doi.org/10.25561/77735

Wang, Y. (2020). China's ongoing battle against the coronavirus: A scholar-practitioner's experiences and reflections. Socio-Ecological Practice Research. https://doi.org/10.1007/s42532-020-00047-2

Whittemore, R., \& Knafl, K. (2005). The integrative review: Updated methodology. Journal of Advanced Nursing, 52(5), 546-553.

Wind, T. R., Rijkeboer, M., Andersson, G., \& Riper, H. (2020). The COVID-19 pandemic: The 'black swan' for mental health care and a turning point for e-health. Internet Interventions. https://doi.org/10.1016/j.invent.2020.100317

Winters, N., Langer, L., \& Geniets, A. (2018). Scoping review assessing the evidence used to support the adoption of mobile health (mHealth) technologies for the education and training of community health workers (CHWs) in lowincome and middle-income countries. British Medical Journal Open, 8:e019827. doi:10.1136/bmjopen-2017019827

World Health Organization. (April, 2020). Rolling updates on coronavirus disease (COVID-19). Retrieved from www.who.int/emergencies/diseases/novel-coronavirus-2019/events-as-they-happen

Xu, D., \& Jaggars, S.S. (2013). Adaptability to online learning: Differences across types of students and academic subject areas. Retrieved from https://ccrc.tc.columbia.edu/media/k2/attachments/adaptability-to-onlinelearning.pdf 
Zawacki-Richter, O., Marín, V. I., Bond, M., \& Gouverneur, F. (2019). Systematic review of research on artificial intelligence applications in higher education - Where are the educators? International Journal of Educational Technology in Higher Education, 16, Art. 39, 1-27. https://doi.org/10.1186/s41239-019-0171-0

Zhou, L., Li, F., Wu, S., Zhou, M. (2020). “School's out, but class's on”, the largest online education in the world today: Taking China's practical exploration during the covid-19 epidemic prevention and control as an example. Best Evidence of Chinese Education, 4(2), 501-519. doi: 10.15354/bece.20.ar023.

Zhu, X., \& Liu, J. (2020). Education in and after Covid-19: Immediate responses and long-term visions. Postdigital Science and Education. https://doi.org/10.1007/s42438-020-00126-3

Zoom. (2020). This post has been updated to reflect new Zoom offerings and resources for educators in response to the COVID-19 (coronavirus) pandemic. Retrieved from https://blog.zoom.us/wordpress/2020/03/29/how-touse-zoom-for-online-learning/

\section{Tables}

Table 1. General OTL tools and resources

\begin{tabular}{|l|l|}
\hline Name of resource/tool & Description \\
\hline Zoom & Free online video conferencing tool* \\
\hline Google Hangouts & Free online video conference tool \\
\hline Microsoft Teams & Free online video conferencing tool* \\
\hline RingCentral & Free online video conferencing tool \\
\hline LogMeIn & Free online video conferencing tool \\
\hline Loom & Free online video recording and sharing tool* \\
\hline Intermedia & Free online video conferencing tool \\
\hline 8x8 & Free online video meeting service \\
\hline Jamm & Free audio-visual tool for distributed and remote teams* \\
\hline Vidyard & Free online video messaging tool (50 participants limit) \\
\hline Discord & Free online live-streaming service \\
\hline Bloomz & Communication service allowing real-time updates* \\
\hline Slack & Remote online collaboration tool \\
\hline VoiceThreads & A suite of online collaboration tools* \\
\hline Zoho & Free online suite of remote aps until July 2020 \\
\hline Google Drive & Free online storage \& file sharing tool* \\
\hline Dropbox & Free online storage \& file sharing tool* \\
\hline Box & Free online storage \& file sharing tool* \\
\hline OneDrive & Free online storage \& file sharing tool \\
\hline
\end{tabular}

Compiled and modified from Soccolich (2020)

* = restrictions often associated with premium subscriptions temporarily lifted for designated months during the COVID-19 outbreak

Table 2. Purpose-specific OTL tools and resources 


\begin{tabular}{|l|l|}
\hline $\begin{array}{l}\text { Name of } \\
\text { resource/tool }\end{array}$ & Description \\
\hline Scholastic & Free five days of academic content \\
\hline Crowdmark & Free access to online grading and analytics platform \\
\hline ClassTag & $\begin{array}{l}\text { Multi-purpose platform (e.g., posting assignment \& short video clips, running } \\
\text { virtual lessons, etc.) } \\
\text { content, and set group work }\end{array}$ \\
\hline Teamplace & $\begin{array}{l}\text { Ontine to distribute teaching materials, edit teaching } \\
\text { Educligent } \\
\text { smation multimedia courseware site allowing HEIs to build online courses on }\end{array}$ \\
\hline $\begin{array}{l}\text { Babbel } \\
\text { language app }\end{array}$ & Offering college students a free 3-month access until mid-June 2020 \\
\hline $\begin{array}{l}\text { Mango } \\
\text { Classroom } \\
\text { app }\end{array}$ & Providing free access to 70 world language to staff and students until end of 2020 \\
\hline $\begin{array}{l}\text { Canvas for } \\
\text { education }\end{array}$ & $\begin{array}{l}\text { The platform allows students to create presentations, reports, worksheets, } \\
\text { infographics, websites, posters and flyers for free. }\end{array}$ \\
\hline $\begin{array}{l}\text { Lumen } \\
\text { Learning }\end{array}$ & Offering free courseware for those wanting to transition to online delivery \\
\hline TutorOcean & Free online tutoring platform for HEIs \\
\hline $\begin{array}{l}\text { Sidecar } \\
\text { Learning }\end{array}$ & Offering HEIs (including colleges) free e-learning platform until May 2020 \\
\hline $\begin{array}{l}\text { Microsoft } \\
\text { Teams }\end{array}$ & $\begin{array}{l}\text { Providing free access staff, faculty and students for six months during the COVID- } \\
\text { 19 outbreak. }\end{array}$ \\
\hline Otter.ai & $\begin{array}{l}\text { Allows 2 free months for 10 staff and faculty per HEI to access its AI-generated } \\
\text { searchable notes, and can be used in conjunction with Microsoft Teams, Zoom, } \\
\text { Google Hangouts and WebEx. }\end{array}$ \\
\hline Free LogMeIn products available to HEIs and colleges for 3 months \\
\hline $\begin{array}{l}\text { LogMeIn kigher Ed } \\
\text { Remote } \\
\text { Learning } \\
\text { Pulse }\end{array}$ & $\begin{array}{l}\text { Free online resource that detects areas of continual improvement in distance } \\
\text { learning, and establishes how prepared faculty and students are for remote } \\
\text { learning. }\end{array}$ \\
\hline Coursera & Offering free access to its courses for universities affected by coronavirus \\
\hline
\end{tabular}

Compiled and modified from Blackburn (2020) and Soccolich (2020)

Table 3. Tech companies providing free and discounted OTL tools and resources 


\begin{tabular}{|c|c|}
\hline $\begin{array}{l}\text { Name of tech } \\
\text { company }\end{array}$ & Resource/Tool description \\
\hline $\begin{array}{l}365 \text { Data } \\
\text { Science }\end{array}$ & $\begin{array}{l}\text { Offering free access to its Data Science Online resource to user until } 15 \text { April } \\
\text { 2020. Coverage includes statistics, Python, maths, machine and deep learning, } \\
\text { and data visualisation. }\end{array}$ \\
\hline Acer & Design a table that offers an over of remote learning tools \\
\hline Adobe & Providing free access to its Creative Cloud tools to students until May 2020 \\
\hline $\begin{array}{l}\text { EdPlus } \\
\text { (Arizona } \\
\text { State } \\
\text { University) }\end{array}$ & $\begin{array}{l}\text { Offering a series of entry-level course videos on areas such as English } \\
\text { composition. }\end{array}$ \\
\hline $\begin{array}{l}\text { Barnes \& } \\
\text { Noble } \\
\text { Education }\end{array}$ & $\begin{array}{l}\text { Making its digital self-tutoring and writing services freely available to college } \\
\text { students }\end{array}$ \\
\hline BibliU & $\begin{array}{l}\text { Making its platform free until } 31 \text { May } 2020 \text { for accessing textbook, monographs } \\
\text { and open educational resources provided by participating publishers. }\end{array}$ \\
\hline BombBomb & $\begin{array}{l}\text { Allowing free access to its software by instructors for recording and sending } \\
\text { video messages about feedback }\end{array}$ \\
\hline Casio & Making its resources available for maths and statistics \\
\hline CirOlive & To freely connect web-based conferencing platforms to LMSs for 90 days \\
\hline Cisco & $\begin{array}{l}\text { Offering its Webex Education software on 90-day free trial during the COVID-19 } \\
\text { outbreak }\end{array}$ \\
\hline Hargray & $\begin{array}{l}\text { To offer free Internet service to college students for } 60 \text { days during the } \\
\text { coronavirus pandemic }\end{array}$ \\
\hline RCampus & $\begin{array}{l}\text { Offering free "Express Edition" licences to universities and colleges to rapidly set } \\
\text { up online classrooms, communicate, share coursework, online grading, etc., until } \\
\text { end of spring } 2020 \text {. }\end{array}$ \\
\hline & \\
\hline
\end{tabular}

Compiled and modified from Bary (2020), Blackburn (2020) and Schaffhauser (2020)

Table 4: U.S. universities $(n=64)$, online delivery modes, online tools and resources, forms of support, reasons for online pivoting, and student offers/concessions 


\begin{tabular}{|c|c|c|c|c|c|c|}
\hline $\begin{array}{l}\text { Name of } \\
\text { university* }\end{array}$ & $\mathrm{OL}^{1}$ & $\mathrm{OT}^{2}$ & OL Tools/Resources & $\begin{array}{l}\mathrm{ERL}^{3} / \mathrm{ERT}^{4} \\
\text { training \& } \\
\text { support } \\
\end{array}$ & Reasons & $\begin{array}{l}\text { Student } \\
\text { Offers or } \\
\text { Concessions } \\
\end{array}$ \\
\hline (1) NYU & $\begin{array}{l}\text { Online } \\
\text { classes }\end{array}$ & $\begin{array}{l}\text { Online } \\
\text { classes }\end{array}$ & $\begin{array}{l}\text { Zoom, Coursera, } \\
\text { posts, chat threads }\end{array}$ & $\begin{array}{l}\text { Webinars, } \\
\text { resources \& } \\
\text { remote } \\
\text { instruction } \\
\text { support for } \\
\text { faculty \& } \\
\text { students }\end{array}$ & $\begin{array}{l}\text { Online } \\
\text { migration due } \\
\text { to } \mathrm{CoV}^{5}\end{array}$ & $\mathrm{~N} / \mathrm{M}^{39}$ \\
\hline $\begin{array}{l}\text { (2) Fort Hays } \\
\text { State Univ }\end{array}$ & $\begin{array}{l}\text { Online } \\
\text { classes }\end{array}$ & $\begin{array}{l}\text { Online } \\
\text { classes }\end{array}$ & $\begin{array}{l}\text { Blackboard (Collaborate), } \\
\text { Zoom, VoiceThread, Vidgrid, } \\
\text { Respondus \& Examity }\end{array}$ & $\begin{array}{l}\text { Resources } \\
\text { for faculty } \\
\& \text { students } \\
\text { for } \\
\text { ERL/ERT }\end{array}$ & $\begin{array}{l}\text { Online } \\
\text { migration due } \\
\text { to COVID-19 }\end{array}$ & $\mathrm{N} / \mathrm{M}$ \\
\hline $\begin{array}{l}\text { (3) Sam } \\
\text { Houston } \\
\text { State Univ }\end{array}$ & $\begin{array}{l}\text { Remote and } \\
\text { online } \\
\text { classes }\end{array}$ & $\begin{array}{l}\text { Remote } \\
\text { and online } \\
\text { classes }\end{array}$ & $\begin{array}{l}\text { Blackboard (Collaborate), } \\
\text { Zoom, Kaltura \& Respondus } \\
\text { Lockdown Browser/Monitor }\end{array}$ & $\begin{array}{l}\text { Guide, } \\
\text { support, } \\
\text { help \& tips } \\
\text { for faculty }\end{array}$ & $\begin{array}{l}\text { Transitioning } \\
\text { to remote } \\
\text { delivery due } \\
\text { to COVID-19 }\end{array}$ & $\mathrm{N} / \mathrm{M}$ \\
\hline $\begin{array}{ll}(4) & \text { Temp } \\
\text { Univ } & \end{array}$ & $\begin{array}{l}\text { Remote } \\
\text { learning and } \\
\text { instruction }\end{array}$ & $\begin{array}{l}\text { Remote } \\
\text { learning } \\
\text { and } \\
\text { instruction }\end{array}$ & $\begin{array}{l}\text { Canvas, Zoom, MS } \\
\text { OWLeams, } \\
\text { OneDrive, Google Drive, } \\
\text { telephone conferencing }\end{array}$ & $\begin{array}{l}\text { Resources } \\
\text { \& guides to } \\
\text { support } \\
\text { faculty to } \\
\text { use } \\
\text { emergency } \\
\text { OT \& OL }\end{array}$ & $\begin{array}{l}\text { Shift to } \\
\text { remote } \\
\text { instruction } \\
\text { due to } \\
\text { COVID-19 }\end{array}$ & $\begin{array}{l}\text { Plans to } \\
\text { freeze } \\
\text { tuition fees } \\
\text { for } 2020- \\
2021 \\
\text { academic } \\
\text { year }\end{array}$ \\
\hline $\begin{array}{l}\text { (5) } \\
\text { Northwestern } \\
\text { Uni }\end{array}$ & $\begin{array}{l}\text { Online } \\
\text { classes }\end{array}$ & $\begin{array}{l}\text { Online } \\
\text { classes }\end{array}$ & $\begin{array}{l}\text { Canvas } \quad\left(\mathrm{LMS}^{6}\right), \quad \text { Zoom, } \\
\text { Panopto \& Respondus }\end{array}$ & $\begin{array}{l}\text { Remote } \\
\text { teaching } \\
\text { assistants, } \\
\text { support, } \\
\text { workshop \& } \\
\text { training for } \\
\text { faculty \& } \\
\text { students } \\
\end{array}$ & $\begin{array}{l}\text { Shift to } \\
\text { remote } \\
\text { instruction } \\
\text { due to } \mathrm{CoV}\end{array}$ & $\mathrm{N} / \mathrm{M}$ \\
\hline $\begin{array}{l}\text { (6) Univ of } \\
\text { Oregon }\end{array}$ & $\begin{array}{l}\text { Remote } \\
\text { learning }\end{array}$ & $\begin{array}{l}\text { Remote } \\
\text { teaching }\end{array}$ & Canvas, Zoom \& Kaltura & $\begin{array}{l}\text { Resources, } \\
\text { support \& } \\
\text { training for } \\
\text { faculty \& } \\
\text { students }\end{array}$ & $\begin{array}{l}\text { Remote } \\
\text { teaching due } \\
\text { to COVID-19 }\end{array}$ & $\mathrm{N} / \mathrm{M}$ \\
\hline $\begin{array}{l}\text { (7) Univ of } \\
\text { Florida }\end{array}$ & $\begin{array}{l}\text { Remote } \\
\text { instruction }\end{array}$ & $\begin{array}{l}\text { Remote } \\
\text { instruction }\end{array}$ & $\begin{array}{l}\text { Canvas/Plaza, Zoom, Skype, } \\
\text { Discord \& Hangouts }\end{array}$ & $\begin{array}{l}\text { Help, tips } \\
\text { \& guides } \\
\text { for faculty }\end{array}$ & $\begin{array}{l}\text { Online } \\
\text { migration due } \\
\text { to COVID-19 }\end{array}$ & $\mathrm{N} / \mathrm{M}$ \\
\hline (8) Hav Uni & $\begin{array}{l}\text { Online-only } \\
\text { classes } \\
\left(\mathrm{LCA}^{8}\right)\end{array}$ & \begin{tabular}{|l|} 
Online- \\
only \\
classes \\
(LCA) \\
\end{tabular} & $\begin{array}{l}\text { Zoom, Canvas, MS Teams, } \\
\text { Slack \& OneDrive }\end{array}$ & $\begin{array}{l}\begin{array}{l}\text { Tools, } \\
\text { advice \& } \\
\text { support for } \\
\text { faculty }\end{array} \\
\end{array}$ & $\begin{array}{l}\text { Shift ro } \\
\text { ERL/ERT due } \\
\text { to COVID-19 }\end{array}$ & $\mathrm{N} / \mathrm{M}$ \\
\hline $\begin{array}{l}\text { (9) } \\
\text { University of } \\
\text { Maryland, } \\
\text { Baltimore } \\
\text { County }\end{array}$ & $\begin{array}{l}\text { Remote \& } \\
\text { OL- }\end{array}$ & $\begin{array}{l}\text { Remote \& } \\
\text { OT }\end{array}$ & 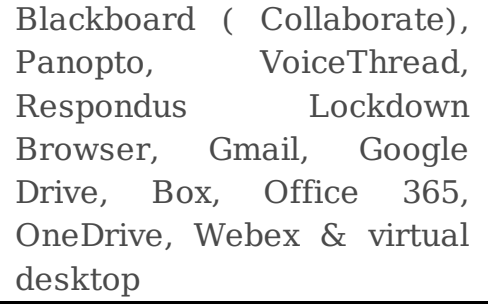 & $\begin{array}{l}\text { Tools, } \\
\text { advice \& } \\
\text { support for } \\
\text { faculty }\end{array}$ & $\begin{array}{l}\text { ERL/ERT due } \\
\text { to COVID- } \\
19 / \mathrm{CoV}\end{array}$ & 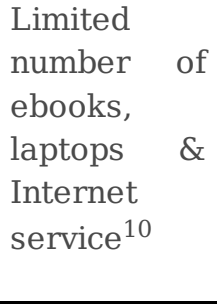 \\
\hline $\begin{array}{l}\text { (10) } \\
\text { CalifIofTech }\end{array}$ & $\begin{array}{l}\text { Online } \\
\text { instruction }\end{array}$ & $\begin{array}{l}\text { Online } \\
\text { instruction }\end{array}$ & $\begin{array}{l}\text { Moodle, Zoom, Google } \\
\text { Drive, Google Hangouts, } \\
\text { Ziteboard, Camtasia \& } \\
\text { Snagit }\end{array}$ & $\begin{array}{l}\text { Faculty } \\
\text { guide } \& \\
\text { student } \\
\text { support for }\end{array}$ & $\begin{array}{l}\text { Online } \\
\text { migration }^{11} \\
\text { due } \\
\text { COVID-19 }\end{array}$ & $\mathrm{N} / \mathrm{M}$ \\
\hline
\end{tabular}

Page 35/46 


\begin{tabular}{|c|c|c|c|c|c|c|}
\hline & & & & $\begin{array}{l}\text { online } \\
\text { resources }\end{array}$ & & \\
\hline $\begin{array}{l}(11) \\
\text { Southern } \\
\text { New } \\
\text { Hampshire } \\
\text { Univ }\end{array}$ & $\begin{array}{l}\text { Online } \\
\text { classes }\end{array}$ & $\begin{array}{l}\text { Online } \\
\text { classes }\end{array}$ & $\mathrm{N} / \mathrm{M}$ & $\begin{array}{l}\text { Faculty } \\
\text { resources } \\
\text { and } \\
\text { instructional } \\
\text { tips }\end{array}$ & $\begin{array}{l}\text { ERL/ERT }^{12} \\
\text { due } \\
\text { COVID-19 }\end{array}$ & $\begin{array}{l}\text { Reduced } \\
\text { course fee }\end{array}$ \\
\hline $\begin{array}{l}(12) \\
\text { UnivofWash }\end{array}$ & $\begin{array}{l}\text { Online-only } \\
\text { instruction }\end{array}$ & $\begin{array}{l}\text { Online- } \\
\text { only } \\
\text { instruction }\end{array}$ & $\begin{array}{llll}\text { Canvas, } & \text { Zoom } & \text { Pro } & \& \\
\text { Panopto } & & & \\
\end{array}$ & $\begin{array}{l}\text { To devise a } \\
\text { plan for } \\
\text { various } \\
\text { scenarios }\end{array}$ & $\begin{array}{l}\text { OL \& OT due } \\
\text { to } \mathrm{CoV}\end{array}$ & $\mathrm{N} / \mathrm{M}$ \\
\hline $\begin{array}{l}\text { (13) Ohio } \\
\text { State Univ }\end{array}$ & $\begin{array}{l}\text { Online } \\
\text { classes }\end{array}$ & $\begin{array}{l}\text { Online } \\
\text { classes }\end{array}$ & Carmen \& Zoom & $\begin{array}{l}\text { Student } \\
\text { guide \& } \\
\text { faculty help } \\
\& \\
\text { workshops }\end{array}$ & $\begin{array}{l}\text { Online } \\
\text { migration due } \\
\text { to } \mathrm{CoV}^{14}\end{array}$ & $\mathrm{~N} / \mathrm{M}$ \\
\hline (14) UofIowa & $\begin{array}{l}\text { Online } \\
\text { classes }\end{array}$ & $\begin{array}{l}\text { Online } \\
\text { classes }\end{array}$ & $\begin{array}{lrr}\text { Institutional } & \text { LMS, Zoom, } \\
\text { SharePoint, } & \text { Respondus, } \\
\text { Peerceptiv \& Wiki } & \end{array}$ & $\begin{array}{ll}\text { Faculty } & \& \\
\text { student } & \\
\text { guides } & \& \\
\text { support } & \end{array}$ & $\begin{array}{l}\text { Online } \\
\text { transition due } \\
\text { to COVID- } \\
19^{15}\end{array}$ & $\bar{N} / \mathrm{M}$ \\
\hline $\begin{array}{l}\text { (15) Illinois } \\
\text { State Univ }\end{array}$ & $\begin{array}{l}\text { Virtual } \\
\text { instruction }\end{array}$ & $\begin{array}{l}\text { Virtual } \\
\text { instruction }\end{array}$ & $\begin{array}{l}\text { Zoom, chat rooms \& group } \\
\text { discussions }\end{array}$ & $\mathrm{N} / \mathrm{M}$ & $\begin{array}{l}\text { Online } \\
\text { transition due } \\
\text { to COVID-19 }\end{array}$ & $\begin{array}{l}\text { Emergency } \\
\text { financial } \\
\text { assistance }\end{array}$ \\
\hline $\begin{array}{l}\text { (16) Texas } \\
\text { A\&M Univ }\end{array}$ & $\begin{array}{l}\text { Online } \\
\text { instruction }\end{array}$ & $\begin{array}{l}\text { Online } \\
\text { instruction }\end{array}$ & Canvas \& Zoom & $\begin{array}{l}\text { Faculty } \\
\text { guide \& tips }\end{array}$ & $\begin{array}{l}\text { Online } \\
\text { transition due } \\
\text { to } \mathrm{CoV}\end{array}$ & $\mathrm{N} / \mathrm{M}$ \\
\hline $\begin{array}{l}(17) \\
\text { UoTAustin }\end{array}$ & $\begin{array}{l}\text { Online } \\
\text { instruction }\end{array}$ & $\begin{array}{l}\text { Online } \\
\text { instruction }\end{array}$ & Canvas, Zoom \& Proctorio & $\begin{array}{l}\text { Online } \\
\text { support for } \\
\text { faculty \& } \\
\text { students }\end{array}$ & $\begin{array}{l}\text { Online } \\
\text { transition due } \\
\text { to } \mathrm{CoV}\end{array}$ & $\mathrm{N} / \mathrm{M}$ \\
\hline (18) BaylorU & $\begin{array}{l}\text { Remote } \\
\text { classes }\end{array}$ & $\begin{array}{l}\text { Remote } \\
\text { classes }\end{array}$ & $\begin{array}{l}\text { Canvas, Webex, Kaltura, MS } \\
\text { Teams \& Zoom }\end{array}$ & $\begin{array}{l}\text { Support \& } \\
\text { workshop } \\
\text { for staff }\end{array}$ & $\begin{array}{l}\text { Transition } \\
\text { remote- } \\
\text { classes due to } \\
\text { COVID-19 }\end{array}$ & $\mathrm{N} / \mathrm{M}$ \\
\hline $\begin{array}{l}\text { (19) Seattle } \\
\text { University }\end{array}$ & $\begin{array}{l}\text { Virtual } \\
\text { instruction }\end{array}$ & $\begin{array}{l}\text { Virtual } \\
\text { instruction }\end{array}$ & $\begin{array}{l}\text { Canvas, Webcam, Zoom, MS } \\
\text { Teams, Cisco Jabber, } \\
\text { OneDrive, Team Drive \& } \\
\text { Adobe Creative Cloud (till } \\
\text { July 31) }\end{array}$ & $\begin{array}{l}\text { Support for } \\
\text { faculty and } \\
\text { students }\end{array}$ & $\begin{array}{l}\text { Shift to } \\
\text { virtual } \\
\text { instruction } \\
\text { due to } \mathrm{CoV}\end{array}$ & $\begin{array}{l}\text { Variable } \\
\text { offers from } \\
\text { mobile } \\
\text { network } \\
\text { providers; } \\
\text { some tuition } \\
\text { fees to be } \\
\text { suspended }\end{array}$ \\
\hline $\begin{array}{l}(20) \quad \text { Duke } \\
\text { University }\end{array}$ & $\begin{array}{l}\text { Online } \\
\text { instruction }\end{array}$ & $\begin{array}{l}\text { Online } \\
\text { instruction }\end{array}$ & $\begin{array}{l}\text { Sakai, Zoom, MS Teams, } \\
\text { Panopto \& Box }\end{array}$ & $\begin{array}{l}\text { Faculty } \\
\text { guides \& } \\
\text { resources }\end{array}$ & $\begin{array}{l}\text { Transition to } \\
\text { remote } \\
\text { instruction } \\
\text { due to } \mathrm{CoV} \\
\end{array}$ & $\begin{array}{l}\text { Emergency } \\
\text { funding }\end{array}$ \\
\hline $\begin{array}{l}\text { (21) Georgia } \\
\text { State Univ }\end{array}$ & $\begin{array}{l}\text { Online } \\
\text { classes }\end{array}$ & $\begin{array}{l}\text { Online } \\
\text { classes }\end{array}$ & $\begin{array}{lr}\text { Institutional LMS, } & \text { Kaltura, } \\
\text { YouTube, } & \text { LinkedIn } \\
\text { Learning, } & \text { Khan, } \\
\text { AcademyMerlot, Webex, MS } \\
\text { Teams \& vLab }\end{array}$ & $\begin{array}{l}\text { Virtual drop- } \\
\text { in \& } \\
\text { webinar } \\
\text { support } \\
\text { sessions; } \\
\text { student } \\
\text { resources }\end{array}$ & $\begin{array}{l}\text { Transition to } \\
\text { online } \\
\text { instruction } \\
\text { due to } \mathrm{CoV}\end{array}$ & $\mathrm{N} / \mathrm{M}$ \\
\hline $\begin{array}{l}\text { (22) Indiana } \\
\text { University }\end{array}$ & $\begin{array}{l}\text { Online } \\
\text { learning }\end{array}$ & $\begin{array}{l}\text { Online } \\
\text { teaching }\end{array}$ & $\begin{array}{l}\text { Canvas, Zoom, Kaltura \& } \\
\text { Boost }\end{array}$ & $\begin{array}{ll}\begin{array}{l}\text { Faculty } \\
\text { student }\end{array} & \& \\
\text { guides } & \& \\
\text { support } & \\
\end{array}$ & $\begin{array}{l}\text { Online-only } \\
\text { instruction } \\
\text { due to } \\
\text { COVID-19 } \\
\end{array}$ & $\mathrm{N} / \mathrm{M}$ \\
\hline
\end{tabular}




\begin{tabular}{|c|c|c|c|c|c|c|}
\hline $\begin{array}{l}\text { (23) Johns } \\
\text { Hopkins Univ }\end{array}$ & $\begin{array}{l}\text { Remote } \\
\text { instruction }{ }^{16}\end{array}$ & $\begin{array}{l}\text { Remote } \\
\text { instruction }\end{array}$ & $\begin{array}{l}\text { Zoom, Panopto, Flipgrid, \& } \\
\text { EdPuzzle }\end{array}$ & $\begin{array}{l}\text { Faculty } \\
\text { guidance }\end{array}$ & $\begin{array}{l}\text { Pivoting to } \\
\text { remote } \\
\text { teaching due } \\
\text { to COVID-19 }\end{array}$ & $\mathrm{N} / \mathrm{M}$ \\
\hline $\begin{array}{l}\text { (24) George } \\
\text { Washington } \\
\text { Univ }\end{array}$ & $\begin{array}{l}\text { Online } \\
\text { instruction }\end{array}$ & $\begin{array}{l}\text { Online } \\
\text { instruction }\end{array}$ & $\begin{array}{l}\text { Blackboard (Collaborate), } \\
\text { Echo360, Collaborate Ultra, } \\
\text { Webex \& Respondus }\end{array}$ & $\begin{array}{l}\text { Faculty } \\
\text { guides, } \\
\text { workshops } \\
\text { \& trainings; } \\
\text { student } \\
\text { resources }\end{array}$ & $\begin{array}{l}\text { Online } \\
\text { transition due } \\
\text { to } \mathrm{CoV}\end{array}$ & $\mathrm{N} / \mathrm{M}$ \\
\hline $\begin{array}{l}\text { (25) Arizona } \\
\text { State Univ }\end{array}$ & $\begin{array}{l}\text { Online } \\
\text { classes }\end{array}$ & $\begin{array}{l}\text { Online } \\
\text { classes }\end{array}$ & Zoom, Canvas \& Slack & $\begin{array}{l}\text { Faculty \& } \\
\text { student } \\
\text { guides }\end{array}$ & $\begin{array}{l}\text { Transition to } \\
\text { remote } \\
\text { instruction } \\
\text { due to } \mathrm{CoV}^{17}\end{array}$ & $\mathrm{~N} / \mathrm{M}$ \\
\hline $\begin{array}{l}\text { (26) Univ of } \\
\text { Oklahoma }\end{array}$ & $\begin{array}{l}\text { Online } \\
\text { classes }\end{array}$ & $\begin{array}{l}\text { Online } \\
\text { classes }\end{array}$ & Canvas \& Zoom & $\begin{array}{l}\text { Faculty } \\
\text { guides \& } \\
\text { trainings; } \\
\text { student } \\
\text { guides } \\
\end{array}$ & $\begin{array}{ll}\text { Transition } & \text { to } \\
\text { remote } & \\
\text { instruction } & \\
\text { due } & \text { to } \\
\text { COVID-19 } & \\
\end{array}$ & $\mathrm{N} / \mathrm{M}$ \\
\hline $\begin{array}{ll}\text { (27) } & \text { Miami } \\
\text { Univ } & \end{array}$ & $\begin{array}{l}\text { Online } \\
\text { instruction }\end{array}$ & $\begin{array}{l}\text { Online } \\
\text { instruction }\end{array}$ & $\begin{array}{l}\text { Canvas, Google } \\
\text { WebEx }\end{array}$ & $\begin{array}{ll}\begin{array}{l}\text { Faculty } \\
\text { student }\end{array} & \& \\
\text { guides } & \& \\
\text { support } & \\
\end{array}$ & $\begin{array}{l}\text { Remote } \\
\text { instruction } \\
\text { due to } \\
\text { COVID-19 } \\
\end{array}$ & $\mathrm{N} / \mathrm{M}$ \\
\hline $\begin{array}{ll}\text { (28) } & \text { Drexel } \\
\text { Univ } & \end{array}$ & $\begin{array}{l}\text { Online } \\
\text { instruction }\end{array}$ & $\begin{array}{l}\text { Online } \\
\text { instruction }\end{array}$ & $\begin{array}{l}\text { Various tools (e.g., MS } \\
\text { Office 365, Zoom, Houdini } \\
\text { FX, Syntheyes \& Adobe } \\
\text { Creative Cloud) }\end{array}$ & $\begin{array}{ll}\begin{array}{l}\text { Faculty } \\
\text { student }\end{array} \\
\text { guides } & \& \\
\text { support } & \end{array}$ & $\begin{array}{l}\text { Remote } \\
\text { instruction } \\
\text { due to } \mathrm{CoV}\end{array}$ & $\begin{array}{l}\text { Loaner } \\
\text { laptops, } \\
\text { free Xfinity } \\
\text { WiFi, free } \\
\text { access to } \\
\text { online } \\
\text { textbooks \& } \\
\text { ebooks, 45 } \\
\text { day free } \\
\text { access to } \\
\text { Accessibyte } \\
\text { Online All } \\
\text { Access, etc. }\end{array}$ \\
\hline $\begin{array}{lr}(29) & \text { City } \\
\text { Univ of New } \\
\text { York }\end{array}$ & $\begin{array}{l}\text { Online } \\
\text { learning }\end{array}$ & $\begin{array}{l}\text { Online } \\
\text { teaching }\end{array}$ & $\begin{array}{l}\text { Blackboard } \text { (Collaborate), } \\
\text { BlueJeans, Zoom, Academic } \\
\text { Commons, OneDrive \& } \\
\text { Dropbox }\end{array}$ & $\begin{array}{lr}\text { Guides } & \text { for } \\
\text { faculty } & \& \\
\text { students } & \end{array}$ & $\begin{array}{l}\text { Online } \\
\text { instruction } \\
\text { due to } \mathrm{CoV}\end{array}$ & $\begin{array}{l}\text { Virtual lab, } \\
\text { computers } \\
\& \text { tablets } \\
\text { for needy } \\
\text { students }\end{array}$ \\
\hline $\begin{array}{l}\text { (30) Cornell } \\
\text { University }\end{array}$ & $\begin{array}{l}\text { Online } \\
\text { classes }\end{array}$ & $\begin{array}{l}\text { Online } \\
\text { classes }\end{array}$ & $\begin{array}{l}\text { Canvas, Panopto, Kaltura \& } \\
\text { Zoom }^{18}\end{array}$ & $\begin{array}{lr}\text { Guides } & \text { for } \\
\text { staff } & \& \\
\text { students } & \\
\end{array}$ & $\begin{array}{l}\text { Distance } \\
\text { learning due } \\
\text { to } \mathrm{CoV}\end{array}$ & $\mathrm{N} / \mathrm{M}$ \\
\hline $\begin{array}{l}(31) \\
\text { Kentucky } \\
\text { State Univ }\end{array}$ & $\begin{array}{l}\text { Online } \\
\text { learning }\end{array}$ & $\begin{array}{l}\text { Online } \\
\text { teaching }\end{array}$ & Blackboard \& Zoom & $\begin{array}{l}\text { Remote, } \\
\text { modified } \\
\text { instruction }\end{array}$ & $\begin{array}{ll}\text { Remote, } & \\
\text { modified } & \\
\text { instruction } & \\
\text { due } & \text { to } \\
\text { COVID-19 } & \end{array}$ & $\begin{array}{l}\text { Student } \\
\text { emergency } \\
\text { fund }\end{array}$ \\
\hline $\begin{array}{l}\text { (32) North } \\
\text { Carolina } \\
\text { State Univ }\end{array}$ & $\begin{array}{l}\text { Online } \\
\text { learning }\end{array}$ & $\begin{array}{l}\text { Online } \\
\text { teaching }\end{array}$ & $\begin{array}{l}\text { Moodle, Zoom, MyMedia, } \\
\text { WolfWare Google Groups, } \\
\text { Google Suite, Google Drive } \\
\text { \& Respondus }\end{array}$ & $\begin{array}{lr}\text { Training } \& \\
\text { help for } \\
\text { faculty }\end{array}$ & $\begin{array}{l}\text { Transition to } \\
\text { fully online } \\
\text { courses due } \\
\text { to } \mathrm{CoV}^{19}\end{array}$ & $\begin{array}{l}\text { Temporary } \\
\text { free access } \\
\text { to ebooks }\end{array}$ \\
\hline $\begin{array}{l}\text { (33) Portland } \\
\text { State Univ }\end{array}$ & $\begin{array}{l}\text { Remote } \\
\text { learning and } \\
\text { online } \\
\text { services } \\
\end{array}$ & $\begin{array}{l}\text { Remote } \\
\text { learning } \\
\text { and online } \\
\text { services }\end{array}$ & $\begin{array}{l}\text { Institutional LMS, Zoom, } \\
\text { Hangouts, Media Space \& } \\
\text { Kaltura Capture }\end{array}$ & $\begin{array}{l}\text { Guides, } \\
\text { suggestions, } \\
\text { tips \& help } \\
\text { for faculty }\end{array}$ & $\begin{array}{lr}\text { Move } & \text { to } \\
\text { remote } & \\
\text { delivery due } \\
\text { to } \mathrm{CoV}^{20}\end{array}$ & $\mathrm{~N} / \mathrm{M}$ \\
\hline
\end{tabular}




\begin{tabular}{|c|c|c|c|c|c|c|}
\hline $\begin{array}{l}\text { (34) Purdue } \\
\text { University }\end{array}$ & $\begin{array}{l}\text { Remote or } \\
\text { online } \\
\text { learning }\end{array}$ & $\begin{array}{l}\text { Remote or } \\
\text { online } \\
\text { teaching }\end{array}$ & $\begin{array}{l}\text { Blackboard } \\
\text { Brightspace, } \\
\text { GoogleMeets, Skype, Zoom } \\
\text { \& GroupMe }\end{array}$ & $\begin{array}{l}\text { Faculty \& } \\
\text { student } \\
\text { guide \& } \\
\text { support for } \\
\text { remote } \\
\text { learning }\end{array}$ & $\begin{array}{l}\text { Remote } \\
\text { instruction } \\
\text { due to } \\
\text { COVID-19 }\end{array}$ & $\begin{array}{l}\text { Free } \\
\text { Internet } \\
\text { services } \\
\text { from } \\
\text { various } \\
\text { providers }\end{array}$ \\
\hline $\begin{array}{l}\text { (35) San } \\
\text { Francisco } \\
\text { State Univ }\end{array}$ & $\begin{array}{l}\text { Remote } \\
\text { (online) } \\
\text { instruction }\end{array}$ & $\begin{array}{l}\text { Remote } \\
\text { (online) } \\
\text { instruction }\end{array}$ & $\begin{array}{l}\text { Institutional LMS, Zoom, } \\
\text { clickers, CourseStream \& } \\
\text { DIVA }\end{array}$ & $\begin{array}{l}\text { Faculty } \\
\text { guide for } \\
\text { remote } \\
\text { teaching }\end{array}$ & $\begin{array}{l}\text { Transition to } \\
\text { remote } \\
\text { instruction } \\
\text { due to } \\
\text { COVID-1921 }\end{array}$ & $\mathrm{N} / \mathrm{M}$ \\
\hline $\begin{array}{l}\text { (36) Fordham } \\
\text { Uni }\end{array}$ & $\begin{array}{l}\text { Offering } \\
\text { selection of } \\
\text { online } \\
\text { courses }\end{array}$ & $\begin{array}{l}\text { Offering } \\
\text { selection } \\
\text { of online } \\
\text { courses }\end{array}$ & $\begin{array}{l}\text { Blackboard (Collaborate), } \\
\text { Zoom, WebEx, Google } \\
\text { Hangouts Meets }\end{array}$ & $\begin{array}{l}\text { Faculty \& } \\
\text { student } \\
\text { guides for } \\
\text { remote } \\
\text { instruction }\end{array}$ & $\begin{array}{l}\text { Selection of } \\
\text { OL courses } \\
\text { due to } \\
\text { COVID-1923 }\end{array}$ & $\begin{array}{l}\text { 60-day free } \\
\text { WiFi }\end{array}$ \\
\hline $\begin{array}{l}\text { (37) Adelphi } \\
\text { Univ }\end{array}$ & $\begin{array}{l}\text { Remote } \\
\text { virtual } \\
\text { classes }\end{array}$ & $\begin{array}{l}\text { Remote } \\
\text { virtual } \\
\text { classes }\end{array}$ & $\begin{array}{l}\text { Moodle, Zoom \& Google } \\
\text { Chat }\end{array}$ & $\begin{array}{l}\text { Staff } \& \\
\text { student } \\
\text { guides for } \\
\text { remote } \\
\text { resources }\end{array}$ & $\begin{array}{l}\text { Shift to } \\
\text { virtual } \\
\text { classes due to } \\
\text { CoV }^{24}\end{array}$ & $\begin{array}{l}\text { Adobe } \\
\text { Creative } \\
\text { Cloud \& } \\
\text { free limited } \\
\text { WiFi from } \\
\text { given } \\
\text { providers }\end{array}$ \\
\hline $\begin{array}{l}(38) \\
\text { Columbia } \\
\text { Univ }\end{array}$ & $\begin{array}{l}\text { Online } \\
\text { classes }\end{array}$ & $\begin{array}{l}\text { Online } \\
\text { classes }\end{array}$ & $\begin{array}{lr}\text { Canvas, Zoom, } & \text { Panopto, } \\
\text { EdBlogs, } & \text { LionMail, } \\
\text { Mediathread, Wikispaces, } \\
\text { LinkedIn Learning \& Office } \\
365\end{array}$ & $\begin{array}{l}\text { Faculty } \\
\text { guide, help } \\
\text { \& support }\end{array}$ & $\begin{array}{l}\text { Transition to } \\
\text { remote } \\
\text { classes due to } \\
\mathrm{CoV}\end{array}$ & $\mathrm{N} / \mathrm{M}$ \\
\hline $\begin{array}{l}\text { (39) } \\
\text { Syracuse } \\
\text { Univ }\end{array}$ & $\begin{array}{l}\text { Online } \\
\text { learning }\end{array}$ & $\begin{array}{l}\text { Online } \\
\text { teaching }\end{array}$ & $\begin{array}{l}\text { Blackboard (Collaborate), } \\
\text { MS Teams, Google Meets, } \\
\text { Zoom, G Suite, LinkedIn } \\
\text { Learning, Confluence, Office } \\
\text { 365, OneDrive, Google } \\
\text { Drive, etc. }\end{array}$ & $\begin{array}{l}\text { Staff OT } \\
\text { guide and } \\
\text { resources \& } \\
\text { laptops for } \\
\text { eligible } \\
\text { staff }\end{array}$ & $\begin{array}{l}\text { Transition to } \\
\text { online course } \\
\text { delivery due } \\
\text { to COVID- } \\
19^{25}\end{array}$ & $\mathrm{~N} / \mathrm{M}$ \\
\hline $\begin{array}{ll}\text { (40) } & \text { Yale } \\
\text { Univ } & \end{array}$ & $\begin{array}{l}\text { Online } \\
\text { classes }\end{array}$ & $\begin{array}{l}\text { Online } \\
\text { classes }\end{array}$ & $\begin{array}{l}\text { Zoom, Canvas } \& \text { other } \\
\text { online tools }\end{array}$ & $\begin{array}{l}\text { Faculty } \\
\text { guidelines } \\
\& \\
\text { suggestions } \\
\text { for OT }\end{array}$ & Shift to OL\&T & $\mathrm{N} / \mathrm{M}$ \\
\hline $\begin{array}{l}\text { (41) Univ of } \\
\text { Maryland }\end{array}$ & $\begin{array}{l}\text { Virtual } \\
\text { instruction }\end{array}$ & $\begin{array}{l}\text { Virtual } \\
\text { instruction }\end{array}$ & $\begin{array}{l}\text { Various tools } \text { (Canvas, } \\
\text { Webex, Zoom, Piazza, } \\
\text { Google Hangouts (Meets) \& } \\
\text { Panopto) }\end{array}$ & $\begin{array}{l}\text { Faculty } \\
\text { guidelines } \\
\text { for remote } \\
\text { resources }\end{array}$ & $\begin{array}{lr}\text { Shift } & \text { to } \\
\text { remote } & \text { class } \\
\text { delivery due } \\
\text { to } \quad \text { COVID- } \\
19^{26}\end{array}$ & $\overline{N / M}$ \\
\hline $\begin{array}{l}(42) \quad \text { Penn } \\
\text { State Univ }\end{array}$ & $\begin{array}{l}\text { Remote } \\
\text { class } \\
\text { delivery }\end{array}$ & $\begin{array}{l}\text { Remote } \\
\text { class } \\
\text { delivery }\end{array}$ & $\begin{array}{l}\text { Canvas, Office 365, MS } \\
\text { Teams, Zoom, Cisco Jabber, } \\
\text { Virtual Desktop, OneDrive \& } \\
\text { Box }\end{array}$ & $\begin{array}{l}\text { Online help } \\
\text { \& FAQs for } \\
\text { remote } \\
\text { teaching }\end{array}$ & $\begin{array}{lr}\text { Shift } & \text { to } \\
\text { remote } & \text { class } \\
\text { delivery due } \\
\text { to } \quad \text { COVID- } \\
19^{27}\end{array}$ & $\overline{N / M}$ \\
\hline $\begin{array}{l}\text { (43) Univ of } \\
\text { South } \\
\text { Carolina }\end{array}$ & $\begin{array}{ll}\text { On-line } & \text { or } \\
\text { distance } & \\
\text { learning } & \end{array}$ & $\begin{array}{l}\text { On-line or } \\
\text { distance } \\
\text { teaching }\end{array}$ & $\begin{array}{l}\text { Blackboard (Collaborate) } \\
\text { Ultra, YouTube, GroupMe, } \\
\text { Messenger, WhatsApp, } \\
\text { Instagram, Facebook, Wiki, } \\
\text { Office 365, Screencastify, } \\
\text { Screencast-o-matic, Skype, } \\
\begin{array}{ll}\text { MS Teams, Google } \\
\text { Hangouts, Ted Talks, }\end{array}\end{array}$ & $\begin{array}{l}\text { Virtual drop- } \\
\text { in } \& \\
\text { training for } \\
\text { faculty }\end{array}$ & $\begin{array}{lr}\text { Move } & \text { to } \\
\text { remote } & \\
\text { teaching } & \text { due } \\
\text { to } \mathrm{CoV}^{28} & \end{array}$ & $\begin{array}{l}\text { Free access } \\
\text { to digital } \\
\text { publications } \\
\text { from } \\
\text { selected } \\
\text { publishers }\end{array}$ \\
\hline
\end{tabular}




\begin{tabular}{|c|c|c|c|c|c|c|}
\hline & & & $\begin{array}{l}\text { OneDrive, Outlook } 365 \& \text { \& } \\
\text { Respondus } \\
\text { Browser }\end{array}$ & & & \\
\hline $\begin{array}{l}\text { (44) Univ of } \\
\text { Chicago }\end{array}$ & $\begin{array}{l}\text { Remote } \\
\text { instruction }\end{array}$ & $\begin{array}{l}\text { Remote } \\
\text { instruction }\end{array}$ & Canvas, Zoom \& Panopto & $\begin{array}{l}\text { Faculty } \\
\text { guidelines } \\
\& \quad \text { virtual } \\
\text { training for } \\
\text { remote } \\
\text { resources }\end{array}$ & $\begin{array}{l}\text { Transition to } \\
\text { remote } \\
\text { instruction } \\
\text { due to } \\
\text { COVID-19 }\end{array}$ & $\begin{array}{l}\text { Student } \\
\text { feedback; } \\
\text { food } \\
\text { security \& } \\
\text { emergency } \\
\text { assistance }\end{array}$ \\
\hline $\begin{array}{l}\text { (45) Univ of } \\
\text { Michigan }\end{array}$ & $\begin{array}{l}\text { Remote } \\
\text { learning }\end{array}$ & $\begin{array}{l}\text { Remote } \\
\text { teaching }\end{array}$ & $\begin{array}{l}\text { Canvas, Zoom, BlueJeans \& } \\
\text { Google Chat, }\end{array}$ & $\begin{array}{l}\text { Training } \\
\text { sessions for } \\
\text { faculty }\end{array}$ & $\begin{array}{l}\text { Move to } \\
\text { remote } \\
\text { formats due } \\
\text { to } \mathrm{CoV}^{30}\end{array}$ & $\mathrm{~N} / \mathrm{M}$ \\
\hline $\begin{array}{l}\text { (46) Univ of } \\
\text { Minnesota }\end{array}$ & $\begin{array}{l}\text { Online } \\
\text { learning }\end{array}$ & $\begin{array}{l}\text { Online } \\
\text { teaching }\end{array}$ & Zoom & $\begin{array}{l}\text { Guides, } \\
\text { suggestions, } \\
\text { tips \& help } \\
\text { for faculty } \\
\text { about using } \\
\text { Zoom } \\
\end{array}$ & $\begin{array}{l}\text { Move } r \\
\text { online classes } \\
\text { die to COVID- } \\
19\end{array}$ & $\mathrm{~N} / \mathrm{M}$ \\
\hline $\begin{array}{l}\text { (47) Univ of } \\
\text { Missouri }\end{array}$ & $\begin{array}{l}\text { Online or } \\
\text { remote } \\
\text { delivery }\end{array}$ & \begin{tabular}{ll|} 
Online & or \\
remote & \\
delivery &
\end{tabular} & $\begin{array}{l}\text { Tools such as Canvas, Zoom } \\
\text { \& Panopto }\end{array}$ & $\begin{array}{l}\text { Trainings \& } \\
\text { guides for } \\
\text { instructor } \\
\text { and student } \\
\text { resources } \\
\end{array}$ & $\begin{array}{l}\text { Transition to } \\
\text { amended } \\
\text { delivery } \\
\text { modes due to } \\
\text { COVID-19 }\end{array}$ & $\overline{\mathrm{N} / \mathrm{M}}$ \\
\hline $\begin{array}{l}\text { (48) Howard } \\
\text { Univ }\end{array}$ & $\begin{array}{l}\text { Online } \\
\text { instruction }\end{array}$ & $\begin{array}{l}\text { Online } \\
\text { instruction }\end{array}$ & Blackboard \& Zoom & $\begin{array}{l}\text { Trainings, } \\
\text { help \& } \\
\text { support for } \\
\text { faculty }\end{array}$ & $\begin{array}{l}\text { Transition to } \\
\text { remote/online } \\
\text { instruction } \\
\text { due to } \\
\text { COVID-1931 }\end{array}$ & $\begin{array}{l}\text { Emergency } \\
\text { scholarship } \\
\text { fund }\end{array}$ \\
\hline $\begin{array}{l}\text { (49) Univ of } \\
\text { Delaware }\end{array}$ & $\begin{array}{l}\text { Virtual } \\
\text { classes }\end{array}$ & $\begin{array}{l}\text { Virtual } \\
\text { classes }\end{array}$ & $\begin{array}{lcc}\text { Canvas, } & \text { Zoom, } & \text { ExamSoft, } \\
\text { ProctorU } & \& & \text { LockDown } \\
\text { Browser } & & \\
& & \end{array}$ & $\begin{array}{l}\text { Guide to } \\
\text { resources } \\
\text { for staff }\end{array}$ & $\begin{array}{l}\text { Move to } \\
\text { virtual } \\
\text { classes due to } \\
\text { COVID-19 }\end{array}$ & $\mathrm{N} / \mathrm{M}$ \\
\hline $\begin{array}{l}\text { (50) Univ of } \\
\text { Virginia }\end{array}$ & $\begin{array}{l}\text { Online } \\
\text { classes }\end{array}$ & $\begin{array}{l}\text { Online } \\
\text { classes }\end{array}$ & $\begin{array}{l}\text { Zoom, Panopto, Piazza, } \\
\text { Kaltura, Confluence \& Box }\end{array}$ & $\begin{array}{l}\text { Guide to } \\
\text { resources } \\
\text { for staff }\end{array}$ & $\begin{array}{l}\text { Move to } \\
\text { online classes } \\
\text { due to } \\
\text { COVID-1933 }\end{array}$ & $\mathrm{N} / \mathrm{M}$ \\
\hline $\begin{array}{l}\text { (51) } \text { Boston } \\
\text { Univ }\end{array}$ & $\begin{array}{l}\text { Remote } \\
\text { classes }\end{array}$ & $\begin{array}{l}\text { Remote } \\
\text { classes }\end{array}$ & $\begin{array}{l}\text { Blackboard (Collaborate), } \\
\text { MS Teams, Zoom, Kaltura, } \\
\text { MyMedia, Echo360 \& Office } \\
365\end{array}$ & $\begin{array}{l}\text { Guides \& } \\
\text { tips for } \\
\text { instructor } \\
\text { and student } \\
\text { resources }\end{array}$ & $\begin{array}{l}\text { Remote } \\
\text { classes due to } \\
\mathrm{CoV}^{34}\end{array}$ & $\mathrm{~N} / \mathrm{M}$ \\
\hline $\begin{array}{l}\text { (52) Univ of } \\
\text { Albany }\end{array}$ & $\begin{array}{l}\text { Remote } \\
\text { learning }\end{array}$ & $\begin{array}{l}\text { Remote } \\
\text { teaching }\end{array}$ & $\begin{array}{lr}\text { Blackboard } & \text { (Collaborate), } \\
\text { Ensemble video, } \\
\text { VoiceThread, Zoom, MS } \\
\text { Teams, Jabber, OneDrive for } \\
\text { Business \& Remote Desktop }\end{array}$ & $\begin{array}{l}\text { Guides, } \\
\text { help, tips } \\
\text { and } \\
\text { workshop } \\
\text { for faculty } \\
\end{array}$ & $\begin{array}{l}\text { Shift } \\
\text { remote } \\
\text { delivery due } \\
\text { to COVID- } \\
19^{35}\end{array}$ & \\
\hline $\begin{array}{l}\text { (53) Univ of } \\
\text { Colorado } \\
\text { Boulder }\end{array}$ & $\begin{array}{l}\text { Remote } \\
\text { learning }\end{array}$ & $\begin{array}{l}\text { Remote } \\
\text { teaching }\end{array}$ & $\begin{array}{l}\text { Canvas, Zoom, Kaltura, } \\
\text { Classroom } \\
\text { VoiceThread, iClicker, PhET, } \\
\text { MERLOT, PlayPosit, } \\
\text { Proctorio \& Examity }\end{array}$ & $\begin{array}{l}\text { Guides, } \\
\text { help, tips } \\
\text { and training } \\
\text { for faculty }\end{array}$ & $\begin{array}{l}\text { Remote } \\
\text { classes due to } \\
\text { COVID-1936 }\end{array}$ & $\mathrm{N} / \mathrm{M}$ \\
\hline $\begin{array}{l}\text { (54) UCLA, } \\
\text { Berkeley }\end{array}$ & $\begin{array}{l}\text { Remote } \\
\text { instruction }\end{array}$ & $\begin{array}{l}\text { Remote } \\
\text { instruction }\end{array}$ & $\begin{array}{l}\text { Institutional LMS, Zoom \& } \\
\text { Google Drive }\end{array}$ & $\begin{array}{l}\text { Checklists } \\
\text { for } \\
\text { instructors } \\
\text { \& students }\end{array}$ & $\begin{array}{l}\text { Remote } \\
\text { instruction } \\
\text { due to } \\
\text { COVID-19 }\end{array}$ & $\mathrm{N} / \mathrm{M}$ \\
\hline (55) MIT & Virtual & Virtual & $\begin{array}{lll}\text { Canvas, WebEx, Zoom, } & \text {, }\end{array}$ & Guides, & Remote & $\mathrm{N} / \mathrm{M}$ \\
\hline
\end{tabular}




\begin{tabular}{|c|c|c|c|c|c|c|}
\hline & instruction & instruction & $\begin{array}{l}\text { Office 365, Slack, Piazza, } \\
\text { VOIP console, OneDrive, } \\
\text { Google Suite, Dropbox, } \\
\text { loaner computer }\end{array}$ & $\begin{array}{l}\text { tutorials, } \\
\text { help \& } \\
\text { support for } \\
\text { faculty }\end{array}$ & $\begin{array}{l}\text { instruction } \\
\text { due to } \\
\text { COVID-1938 }\end{array}$ & \\
\hline $\begin{array}{l}\text { (56) Univ of } \\
\text { Southern } \\
\text { Mississippi }\end{array}$ & $\begin{array}{l}\text { Remote } \\
\text { course } \\
\text { formats }\end{array}$ & $\begin{array}{l}\text { Remote } \\
\text { course } \\
\text { formats }\end{array}$ & $\begin{array}{l}\text { Two integrated LMS } \\
\text { platforms, Canvas, Cisco } \\
\text { Webex, Jabber \& Examity }\end{array}$ & $\begin{array}{l}\text { Instructor } \\
\text { resources; } \\
\text { COVID-19 } \\
\text { student } \\
\text { resources, } \\
\text { guides \& } \\
\text { FOCUS blog }\end{array}$ & $\begin{array}{ll}\text { Remote } & \\
\text { instruction } & \\
\text { due } & \text { to } \\
\text { COVID-19 } & \end{array}$ & $\begin{array}{l}\text { Off-campus } \\
\text { student } \\
\text { connectivity } \\
\& \\
\text { eTextbooks }\end{array}$ \\
\hline $\begin{array}{l}\text { (57) } \\
\text { University of } \\
\text { Louisville }\end{array}$ & $\begin{array}{l}\text { Online } \\
\text { learning }\end{array}$ & $\begin{array}{l}\text { Online } \\
\text { teaching }\end{array}$ & $\begin{array}{l}\text { Blackboard (Collaborate), } \\
\text { Panopto, Office } 365 \& \text { } \\
\text { Respondus }\end{array}$ & $\begin{array}{l}\text { Guides, help } \\
\& \text { support } \\
\text { for faculty } \\
\& \text { students }\end{array}$ & $\begin{array}{l}\text { Shift to online } \\
\text { instruction } \\
\text { due to } \\
\text { COVID-19 } \\
\end{array}$ & $\mathrm{N} / \mathrm{M}$ \\
\hline $\begin{array}{l}\text { (58) } \\
\text { University of } \\
\text { Pittsburg }\end{array}$ & $\begin{array}{l}\text { Remote } \\
\text { instruction }\end{array}$ & $\begin{array}{l}\text { Remote } \\
\text { instruction }\end{array}$ & $\begin{array}{l}\text { Blackboard (Collaborate)/ } \\
\text { /CourseWeb, Canvas, } \\
\text { Panopto, Zoom, MS Teams, } \\
\text { Skype, social networking, } \\
\text { podcasts, Gradescope }\end{array}$ & $\begin{array}{l}\text { Workshops, } \\
\text { guides, help } \\
\& \text { support } \\
\text { for faculty } \\
\& \text { students } \\
\end{array}$ & $\begin{array}{ll}\text { Shift } & \text { to } \\
\text { remote } & \\
\text { instruction } & \\
\text { due } & \text { to } \\
\text { COVID-19 } & \\
\end{array}$ & $\mathrm{N} / \mathrm{M}$ \\
\hline $\begin{array}{l}\text { (59) Furman } \\
\text { University }\end{array}$ & $\begin{array}{l}\text { Online } \\
\text { learning }\end{array}$ & $\begin{array}{l}\text { Online } \\
\text { teaching }\end{array}$ & $\begin{array}{lr}\text { Moodle, Zoom, } & \text { Camtasia, } \\
\text { Box, Office } & 365, \\
\text { Hypothes.is, MS Teams, } \\
\text { Skype, WhatsApp, Marco } \\
\text { Polo \& ScreenCast-O-Matic, } \\
\text { Snagit, or Vimeo }\end{array}$ & $\begin{array}{lr}\text { Guides } & \& \\
\text { tips } & \text { for } \\
\text { faculty } & \end{array}$ & $\begin{array}{ll}\text { Move } & \text { to } \\
\text { online } & \\
\text { instruction } & \\
\text { due } & \text { to } \\
\text { COVID-19 } & \end{array}$ & $\mathrm{N} / \mathrm{M}$ \\
\hline $\begin{array}{l}\text { (60) Abilene } \\
\text { Christian } \\
\text { University }\end{array}$ & $\begin{array}{l}\text { Remote } \\
\text { learning }\end{array}$ & $\begin{array}{l}\text { Remote } \\
\text { teaching }\end{array}$ & $\begin{array}{l}\text { Canvas, Zoom \& Lockdown } \\
\text { Browser }\end{array}$ & $\begin{array}{lr}\text { Guides } & \& \\
\text { tips } & \text { for } \\
\text { faculty } & \& \\
\text { students } & \end{array}$ & $\begin{array}{l}\text { Shift to rapid } \\
\text { remote } \\
\text { instruction } \\
\text { due } \\
\text { COVID-19 }\end{array}$ & $\mathrm{N} / \mathrm{M}$ \\
\hline $\begin{array}{l}\text { (61) Utah } \\
\text { State } \\
\text { University }\end{array}$ & $\begin{array}{l}\text { Remote } \\
\text { learning }\end{array}$ & $\begin{array}{l}\text { Remote } \\
\text { teaching }\end{array}$ & $\begin{array}{l}\text { Canvas, Kaltura, Webex, } \\
\text { MyMedia, Google Drive, Box } \\
\text { \& Proctorio }\end{array}$ & $\begin{array}{l}\text { Guides \& } \\
\text { suggestions } \\
\text { for faculty }\end{array}$ & $\begin{array}{l}\text { Shift to } \\
\text { remote } \\
\text { teaching due } \\
\text { to COVID-19 } \\
\end{array}$ & $\mathrm{N} / \mathrm{M}$ \\
\hline $\begin{array}{l}(62) \text { Weber } \\
\text { State } \\
\text { University } \\
\end{array}$ & $\begin{array}{l}\text { Emergency } \\
\text { remote } \\
\text { learning } \\
\end{array}$ & $\begin{array}{l}\text { Emergency } \\
\text { remote } \\
\text { teaching } \\
\end{array}$ & $\begin{array}{lll}\text { Canvas, Google } & \text { Hangouts, } \\
\text { Box, Google } & \text { Drive \& } \\
\text { ProctorU } & & \\
\end{array}$ & $\begin{array}{lr}\text { Guides } & \& \\
\text { tips } & \text { for } \\
\text { faculty } & \\
\end{array}$ & $\begin{array}{l}\text { Move to } \\
\text { emergency } \\
\text { teaching } \\
\end{array}$ & $\mathrm{N} / \mathrm{M}$ \\
\hline $\begin{array}{l}\text { (63) } \\
\text { University of } \\
\text { Rochester }\end{array}$ & $\begin{array}{l}\text { Online } \\
\text { learning }\end{array}$ & $\begin{array}{l}\text { Online } \\
\text { teaching }\end{array}$ & $\begin{array}{l}\text { Blackboard, Zoom, Panopto, } \\
\text { VoiceThread \& a raft of } \\
\text { Windows software tools for } \\
\text { students }\end{array}$ & $\begin{array}{l}\text { Guidance, } \\
\text { Tutorials \& } \\
\text { tips for } \\
\text { faculty }\end{array}$ & $\begin{array}{l}\text { Shift to online } \\
\text { instruction }\end{array}$ & $\mathrm{N} / \mathrm{M}$ \\
\hline $\begin{array}{l}\text { (64) Wake } \\
\text { Forest } \\
\text { University }\end{array}$ & $\begin{array}{l}\text { Remote } \\
\text { instruction } \\
\text { delivery }\end{array}$ & $\begin{array}{l}\text { Remote } \\
\text { instruction } \\
\text { delivery }\end{array}$ & $\begin{array}{l}\text { Canvas, Sakai, Zoom, } \\
\text { Google Drive, Google Meet, } \\
\text { Webex, VoiceThread, } \\
\text { Camtasia \& WakerSpace }\end{array}$ & $\begin{array}{lr}\text { Guides } & \& \\
\text { tips } & \text { for } \\
\text { faculty } & \end{array}$ & $\begin{array}{ll}\text { Shift } & \text { to } \\
\text { remote } & \\
\text { instruction } & \\
\text { delivery } & \\
\end{array}$ & $\mathrm{N} / \mathrm{M}$ \\
\hline
\end{tabular}

${ }^{1}=$ online learning; ${ }^{2}=$ online teaching; ${ }^{3}=$ emergency remote learning; ${ }^{4}=$ emergency remote teaching; ${ }^{5}=$ coronavirus; ${ }^{6}=$ learning management system; ${ }^{7}=$ online exams; ${ }^{8}=$ limit campus accessibility (limit in-person courses $/$ classes); ${ }^{9}=$ all undergraduate face-to-face instruction; ${ }^{10}=$ Provision of laptops and free Internet service to off-campus students with limited access to computers or to the Internet service; ${ }^{11}=$ till 06 April 2020; ${ }^{12}=$ the remainder of the Spring semester; ${ }^{13}=$ till end of Winter quarter; ${ }^{14}=$ one faculty member; ${ }^{15}=$ till Summer; ${ }^{16}=$ till 12 April 2020; ${ }^{17}=$ through Fall and Spring semesters; ${ }^{18}=$ including Zoom Whiteboard; ${ }^{19}=$ to the fullest extent possible; ${ }^{20}=$ for Spring and Summer terms' 21 = till 31 May 2020; ${ }^{23}=$ during May and June 2020; ${ }^{24}=$ till end of 
Spring semester and for Summer session I; ${ }^{25}=$ through to 30 March $2020 ;{ }^{26}=$ till end of academic year; ${ }^{27}=$ all classes till end of Spring 2020 semester except College of Medicine \& classes to be delivered synchronously to mirror scheduled on-camps classes; ${ }^{28}=$ for Spring 2020; ${ }^{29}=$ for Spring and Summer 2020 quarters; ${ }^{30}=$ during the Spring and Summer 2020 terms; $^{31}=$ the remainder of the Spring 2020 semester; ${ }^{32}=$ for June and July 2020; $33=$ remainder of the Spring semester. ${ }^{34}=$ scheduled class sessions; ${ }^{35}=$ effective from 23 March 2020/all Summer courses; ${ }^{36}=$ from 16 March $2020 ;{ }^{37}=$ through the end of this year's Summer Session $A ;{ }^{38}=$ for classes with over 150 students; $^{39}=$ not mentioned

Table 5. Modes of instruction and variations (U.S. universities)

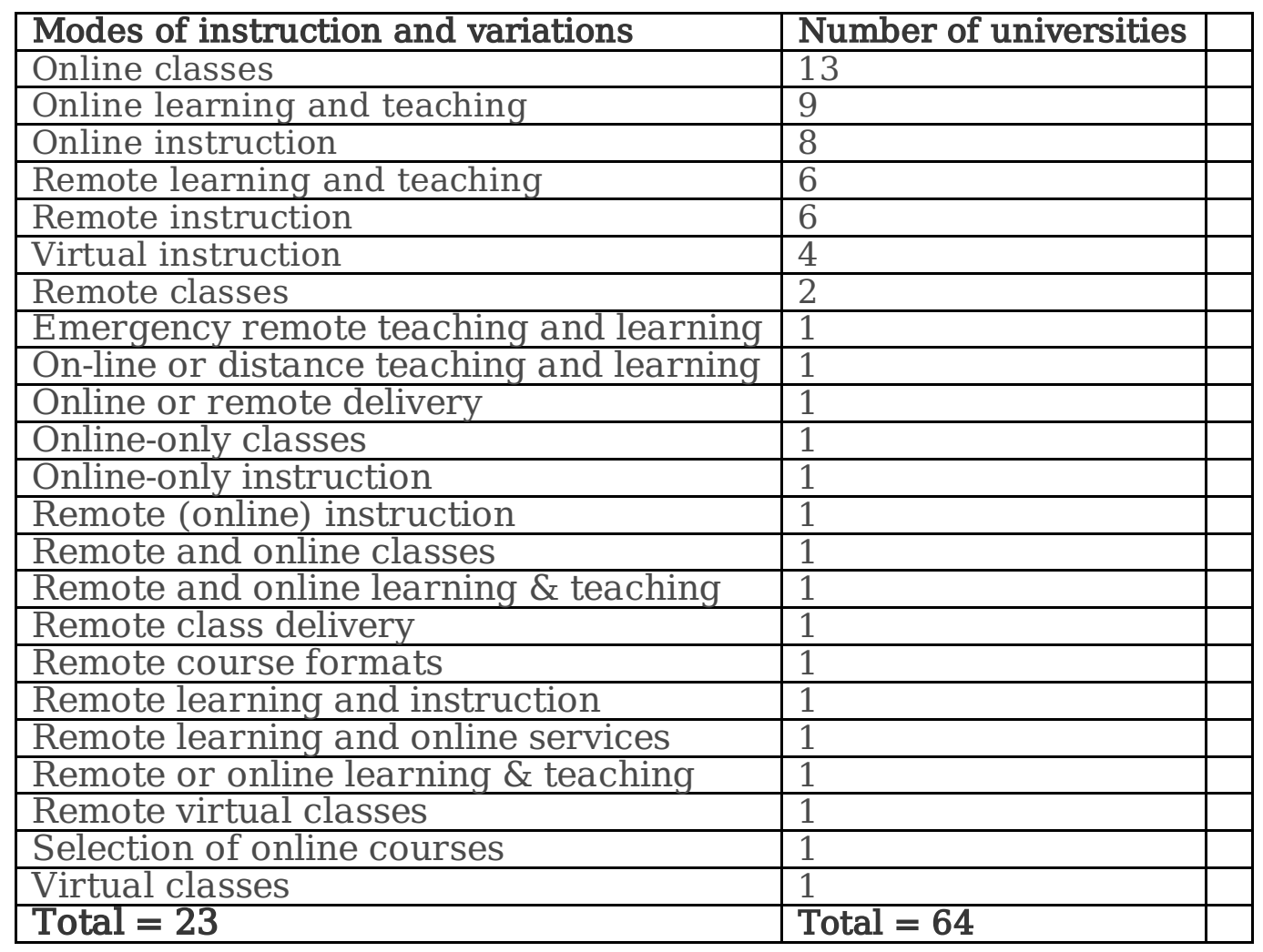

Table 6. Types of online tools and resources (U.S. universities) 


\begin{tabular}{|c|c|c|}
\hline $\begin{array}{l}\text { Types of online } \\
\text { tools and } \\
\text { resources }\end{array}$ & Functions & $\begin{array}{l}\text { Number of } \\
\text { universities }\end{array}$ \\
\hline Zoom & $\begin{array}{l}\text { Online application facilitating video and audio conferencing, } \\
\text { webinars, live chats, screen-sharing, and other collaborative } \\
\text { functions }\end{array}$ & 58 \\
\hline Canvas & $\begin{array}{l}\text { LMS that supports online learning and teaching, and allows for } \\
\text { posting grades, information, and assignments online. }\end{array}$ & 31 \\
\hline $\begin{array}{l}\text { Blackboard } \\
\text { (Collaborate) }\end{array}$ & Online tool offering integrated LMS and conferencing solutions & 16 \\
\hline Panopto & $\begin{array}{l}\text { Online lecture capture tool that enables recording of audios, videos, } \\
\text { slides, and screen capture }\end{array}$ & 14 \\
\hline Microsoft Teams & $\begin{array}{l}\text { Online team owned by Microsoft that has integrated collaboration, } \\
\text { communication and file offerings for virtual teams }\end{array}$ & 13 \\
\hline Webex/WebEx & $\begin{array}{l}\text { Online tool offering messaging, file sharing, white-boarding, video } \\
\text { meetings, calling and more }\end{array}$ & 12 \\
\hline Kaltura & $\begin{array}{l}\text { Online video recording, uploading, sharing, publishing, and } \\
\text { streaming platform }\end{array}$ & 11 \\
\hline $\begin{array}{l}\text { Microsoft Office } \\
365\end{array}$ & $\begin{array}{l}\text { Online tool owned by Microsoft offering integrated virtual Office } \\
\text { documents, spreadsheets and presentations, and a suite of other } \\
\text { office applications }\end{array}$ & 11 \\
\hline $\begin{array}{l}\text { Google } \\
\text { Hangouts/Meets }\end{array}$ & Online video conferencing tool that is part of Google Suite & \begin{tabular}{|l|}
$8+2$ \\
(Google \\
chat)= \\
$(10) ? ?$
\end{tabular} \\
\hline OneDrive & Cloud storage application that is part of Office 365 & 10 \\
\hline Google Drive & Cloud storage application owned by Google & 9 \\
\hline Respondus & $\begin{array}{l}\text { Online assessment proctoring service or system for LMS (in the form } \\
\text { of Respondus Monitor or Respondus LockDown Browser) }\end{array}$ & 9 \\
\hline Box & Cloud storage tool & 7 \\
\hline $\begin{array}{l}\text { Institutional } \\
\text { LMS }\end{array}$ & & 6 \\
\hline VoiceThread & Online platform with voice, video and text commenting capabilities & 6 \\
\hline Proctorio & Online test, assessment. or examination proctoring tool & 5 \\
\hline Skype & $\begin{array}{l}\text { Online video calling and text messaging/chatting tool that is part of } \\
\text { Office } 365\end{array}$ & 5 \\
\hline Google Suite & $\begin{array}{l}\text { Cloud-based collaboration and productivity tools (e.g., Gmail, Docs, } \\
\text { Meet, Calendar, etc.) owned by Google. }\end{array}$ & 4 \\
\hline Jabber & $\begin{array}{l}\text { Integrated online communications service for instant messaging, } \\
\text { voice and video calling, conferencing, desktop sharing, etc., owned } \\
\text { by Cisco }\end{array}$ & 4 \\
\hline Moodle & $\begin{array}{l}\text { Moodle (Modular Object-Oriented Dynamic Learning Environment) } \\
\text { is a free, open-source LMS }\end{array}$ & 4 \\
\hline Camtasia & Screen recording and video editing tool & 3 \\
\hline Examity & Online tool offering examination and proctoring solutions & 3 \\
\hline $\begin{array}{l}\text { LinkedIn } \\
\text { Learning }\end{array}$ & $\begin{array}{l}\text { Online educational platform that helps users discover and develop } \\
\text { creative skills and technology skills via course videos }\end{array}$ & 3 \\
\hline MyMedia & Online file manager & 3 \\
\hline Piazza & $\begin{array}{l}\text { Online platform enabling to engage in students discussion forums } \\
\text { or collaborative interactions under an instructor's guidance }\end{array}$ & 3 \\
\hline Slack & Workplace chat or messaging tool & 3 \\
\hline Virtual desktop & $\begin{array}{l}\text { Remote desktop that users can access anytime, anywhere, from any } \\
\text { device }\end{array}$ & 3 \\
\hline Wiki & $\begin{array}{l}\text { Online application allowing collaborative writing and editing of texts } \\
\text { or documents }\end{array}$ & 3 \\
\hline $\begin{array}{l}\text { Adobe Creative } \\
\text { Cloud }\end{array}$ & Suite of desktop and mobile services and apps for online creatives & 2 \\
\hline BlueJeans & $\begin{array}{l}\text { Platform for live video calls, video conferencing, online meetings, } \\
\text { and screen sharing }\end{array}$ & 2 \\
\hline Clickers & $\begin{array}{l}\text { Response-system based instructional technologies that are capable } \\
\text { of collecting and analysing student responses during instruction }\end{array}$ & 2 \\
\hline Sakai & Open-source LMS for higher education & 2 \\
\hline Screencast-O- & Screen recording and video editing tool & 2 \\
\hline
\end{tabular}

Page $42 / 46$ 
Matic

WhatsApp

Instant messaging application video sharing platform

2

1 = Tools and resources used only once not included

Table 7. South African universities ( $n=21$ ), online delivery modes, online tools and resources, forms of support, reasons for online pivoting, and student offers/concessions 


\begin{tabular}{|c|c|c|c|c|c|c|}
\hline $\begin{array}{l}\text { Name of } \\
\text { university* }\end{array}$ & $\mathrm{OL}^{1}$ & $\mathrm{OT}^{2}$ & $\begin{array}{l}\text { OL } \\
\text { Tools/Resources }\end{array}$ & $\begin{array}{l}\mathrm{ERL}^{3} / \mathrm{ERT}^{4} \\
\text { training \& support }\end{array}$ & Reasons & $\begin{array}{l}\text { Student Offers or } \\
\text { Concessions }\end{array}$ \\
\hline $\begin{array}{l}(1) \\
\text { Rhodes }\end{array}$ & $\begin{array}{l}\text { Online } \\
\text { learning }\end{array}$ & $\begin{array}{l}\text { Online } \\
\text { teaching }\end{array}$ & WhatsApp & $\mathrm{N} / \mathrm{M}$ & $\begin{array}{l}\text { Move to virtual } \\
\text { classes due to } \\
\mathrm{CoV}^{5}\end{array}$ & $\mathrm{~N} / \mathrm{M}^{36}$ \\
\hline (2) UCT & $\begin{array}{l}\text { Online } \\
\text { learning }\end{array}$ & $\begin{array}{l}\text { Online } \\
\text { teaching }\end{array}$ & Institutional LMS & $\begin{array}{l}\text { Remote teaching } \\
\text { orientation }\end{array}$ & $\begin{array}{l}\text { Move to remote } \\
\text { teaching due to } \\
\text { COVID-196 }\end{array}$ & $\begin{array}{l}\text { Zero-rating of } \\
\text { mobile data to } \\
\text { specific online } \\
\text { resources }^{7} ; 30 \text { - } \\
40 \text { GB of data } \\
\end{array}$ \\
\hline $\begin{array}{ll}\text { (3) } & \text { Wits } \\
\text { Univ } & \end{array}$ & $\begin{array}{l}\text { Emergency } \\
\text { online } \\
\text { learning }\end{array}$ & $\begin{array}{l}\text { Emergency } \\
\text { online } \\
\text { teaching }\end{array}$ & Sakai or Moodle & $\mathrm{N} / \mathrm{M}$ & $\begin{array}{l}\text { Commencing } \\
\text { with emergency } \\
\text { remote OT \& } \\
\text { OL due to } \\
\text { COVID-199 }\end{array}$ & $\begin{array}{l}\text { Zero-rating of } \\
\text { online learning \& } \\
\text { library sites; } \\
\text { 30GB of data }{ }^{10}\end{array}$ \\
\hline (4) NWU & $\begin{array}{l}\text { Online } \\
\text { learning }\end{array}$ & $\begin{array}{l}\text { Online } \\
\text { teaching }\end{array}$ & Institutional LMS & $\mathrm{N} / \mathrm{M}$ & $\begin{array}{l}\text { Move to OT- } \\
\text { OL due to } \\
\text { COVID-19 }\end{array}$ & $\begin{array}{l}\text { Zero-rating of } \\
\text { data }^{12}\end{array}$ \\
\hline (5) UJ & $\begin{array}{l}\text { Online } \\
\text { learning }\end{array}$ & $\begin{array}{l}\text { Online } \\
\text { teaching }\end{array}$ & $\begin{array}{l}\text { WhatsApp, } \\
\text { Blackboard } \\
\text { (Collaborate), } \\
\text { Skype \& Zoom }\end{array}$ & $\begin{array}{l}\text { Staff guidelines for } \\
\text { off-campus } \\
\text { resources }\end{array}$ & $\begin{array}{l}\text { Shift to OT due } \\
\text { to COVID-19 } 13\end{array}$ & $\begin{array}{l}\text { Zero-rating of } \\
\text { data and of } \\
\text { certain } \\
\text { institutional } \\
\text { websites }^{14} \\
\end{array}$ \\
\hline (6) SUN & $\begin{array}{l}\text { Online } \\
\text { learning }\end{array}$ & $\begin{array}{l}\text { Online } \\
\text { teachings }\end{array}$ & Institutional LMS & \begin{tabular}{lrr}
\multicolumn{2}{l}{ Webinars } & about \\
OT \& guidelines \\
for OT $\quad$ for \\
academics
\end{tabular} & $\begin{array}{l}\text { Transition to } \\
\text { online lectures } \\
\text { due to COVID- } \\
19^{15}\end{array}$ & \begin{tabular}{lr}
\multicolumn{2}{l}{ Zero-rating data } \\
to institutional \\
LMS $^{\text {streaming }^{16}}$ and \\
\end{tabular} \\
\hline (7) UFS & $\begin{array}{l}\text { Online and } \\
\text { distance } \\
\text { learning }\end{array}$ & $\begin{array}{l}\text { Online and } \\
\text { distance } \\
\text { teaching }\end{array}$ & $\begin{array}{l}\text { Blackboard } \\
\text { (Collaborate) }\end{array}$ & $\begin{array}{lr}\text { Online } & \text { teaching } \\
\text { transition, } & \\
\text { orientation } & \& \\
\text { support for } & \text { staff; } \\
\text { support } & \text { for } \\
\text { students } & \\
\end{array}$ & $\begin{array}{l}\text { Planned } \\
\text { emergency } \\
\text { remote } \\
\text { teaching and } \\
\text { learning due to } \\
\text { COVID-1917 } \\
\end{array}$ & $\begin{array}{l}\text { Negotiating to } \\
\text { have digital } \\
\text { learning website } \\
\text { zero-rated \& } \\
\text { structured data }^{18}\end{array}$ \\
\hline (8) UP & $\begin{array}{l}\text { Online } \\
\text { learning }\end{array}$ & $\begin{array}{l}\text { Online } \\
\text { teaching }\end{array}$ & $\begin{array}{l}\text { Resources such as } \\
\text { Blackboard } \\
\text { (Collaborate), } \\
\text { Google Docs, } \\
\text { Google Dive \& } \\
\text { Respondus }\end{array}$ & $\begin{array}{l}\text { Staff \& students } \\
\text { guides for OT \& } \\
\text { OL resources }\end{array}$ & $\begin{array}{lll}\text { Move to OT } & \& \\
\text { OL due } & \text { to } \\
\text { COVID-19 } & \end{array}$ & $\begin{array}{l}\text { Negotiating with } \\
\text { leading mobile } \\
\text { network providers } \\
\text { to zero-rate to } \\
\text { institutional LMS }\end{array}$ \\
\hline (9) UKZN & $\begin{array}{l}\text { Online } \\
\text { learning }\end{array}$ & $\begin{array}{l}\text { Online } \\
\text { teaching }\end{array}$ & $\begin{array}{l}\text { Moodle, Kaltura, } \\
\text { MS Teams \& } \\
\text { Zoom }\end{array}$ & $\begin{array}{l}\text { A trial period } \\
\text { implemented first }\end{array}$ & $\begin{array}{l}\text { Move to remote } \\
\text { OT \& OL due to } \\
\text { COVID- } 19^{20}\end{array}$ & $\begin{array}{l}\text { Zero-rated data to } \\
\text { specific } \\
\text { institutional } \\
\text { sites }^{21}\end{array}$ \\
\hline (10) NMU & $\begin{array}{l}\text { Five } \\
\text { variations } \\
\text { of a dual } \\
\text { learning } \\
\text { pathway }\end{array}$ & $\begin{array}{l}\text { Five } \\
\text { variations } \\
\text { of a dual } \\
\text { teaching } \\
\text { pathway }\end{array}$ & $\mathrm{N} / \mathrm{M}^{*}$ & $\begin{array}{lr}\text { Guidelines } & \text { for } \\
\text { pathways } & \text { for } \\
\text { teaching } & \text { and } \\
\text { learning } & \end{array}$ & $\begin{array}{l}\text { Implementing } \\
\text { two teaching \& } \\
\text { learning } \\
\text { pathways due } \\
\text { to COVID-19 }\end{array}$ & $\begin{array}{l}\text { Zero-rating of } \\
\text { data }^{22} \& \text { student } \\
\text { laptop offer }\end{array}$ \\
\hline (11) CPUT & $\begin{array}{l}\text { Mixed T\&L } \\
\text { delivery } \\
\text { methods }\end{array}$ & $\begin{array}{l}\text { Mixed T\&L } \\
\text { delivery } \\
\text { methods }\end{array}$ & $\begin{array}{l}\text { Blackboard } \\
\text { (Collaborate), } \\
\text { WhatsApp, } \\
\text { Facebook, etc. }\end{array}$ & $\begin{array}{l}\text { Training/ } \\
\text { Help on technology } \\
\text { use }\end{array}$ & $\begin{array}{l}\text { Move to mixed } \\
\text { T\&L delivery } \\
\text { due to COVID- } \\
19^{23}\end{array}$ & $\begin{array}{l}\text { Devices for some } \\
\text { students \& zero- } \\
\text { rating }^{24}\end{array}$ \\
\hline $\begin{array}{l}(12) \\
\text { Unizulu }\end{array}$ & $\begin{array}{l}\text { Alternate } \\
\text { OL } \\
\text { methods }\end{array}$ & $\begin{array}{l}\text { Alternate } \\
\text { OL } \\
\text { methods }\end{array}$ & $\mathrm{N} / \mathrm{M}$ & $\mathrm{N} / \mathrm{M}$ & $\begin{array}{l}\text { Alternate } \\
\text { OT\&L due to } \\
\text { CoV }\end{array}$ & $\mathrm{N} / \mathrm{M}$ \\
\hline (13) UWC & $\begin{array}{l}\text { Online } \\
\text { learning }\end{array}$ & $\begin{array}{l}\text { Online } \\
\text { teaching }\end{array}$ & Institutional LMS & $\mathrm{N} / \mathrm{M}$ & $\begin{array}{l}\text { Implementing } \\
\text { flexible } \quad T \& L\end{array}$ & $\begin{array}{l}\text { Providing data to } \\
\text { certain students }^{25}\end{array}$ \\
\hline
\end{tabular}




\begin{tabular}{|c|c|c|c|c|c|c|}
\hline & & & & & due to $\mathrm{CoV}$ & $\begin{array}{l}\text { \& zero-rating of } \\
\text { LMS data }\end{array}$ \\
\hline (14) UFH & $\begin{array}{l}\text { Online } \\
\text { platforms }\end{array}$ & $\begin{array}{l}\text { Online } \\
\text { platforms }\end{array}$ & $\begin{array}{l}\text { Blackboard } \\
\text { (Collaborate) \& } \\
\text { other digital } \\
\text { platforms }\end{array}$ & $\mathrm{N} / \mathrm{M}$ & $\begin{array}{l}\text { Making } \\
\text { learning } \\
\text { materials \& } \\
\text { resources } \\
\text { available online } \\
\text { due to COVID- } \\
19^{26}\end{array}$ & $\begin{array}{lrr}\text { A } & \text { discounted } \\
\text { laptop } & \& & \text { free } \\
\text { data } & & \\
\end{array}$ \\
\hline (15) SPU & $\begin{array}{l}\text { Online/ } \\
\text { blended } \\
\text { delivery }\end{array}$ & $\begin{array}{l}\text { Online/ } \\
\text { blended } \\
\text { delivery }\end{array}$ & $\mathrm{N} / \mathrm{M}$ & $\begin{array}{l}\text { Training } \\
\text { programmes for } \\
\text { staff }\end{array}$ & $\begin{array}{l}\text { Transition to } \\
\text { blended OT\&L } \\
\text { due to COVID- } \\
19^{27}\end{array}$ & $\mathrm{~N} / \mathrm{M}$ \\
\hline (16) TUT & $\begin{array}{l}\text { Multimodal } \\
\text { remote } \\
\text { learning }\end{array}$ & $\begin{array}{l}\text { Multimodal } \\
\text { remote } \\
\text { teaching }\end{array}$ & $\mathrm{N} / \mathrm{M}$ & $\mathrm{N} / \mathrm{M}$ & $\begin{array}{l}\text { Rolling out } \\
\text { multimodal } \\
\text { remote } \\
\text { teaching due to } \\
\text { COVID-19 }\end{array}$ & $\begin{array}{lr}\text { To } & \text { conduct } \\
\text { student } & \text { needs } \\
\text { survey }^{28} & \\
\end{array}$ \\
\hline (17) UMP & $\begin{array}{l}\text { Online } \\
\text { learning }\end{array}$ & $\begin{array}{l}\text { Online } \\
\text { teaching }\end{array}$ & Online platforms ${ }^{29}$ & $\begin{array}{ll}\text { Online } & \text { teaching } \\
\text { training } & \end{array}$ & $\begin{array}{l}\text { Online teaching } \\
\text { due to COVID- } \\
19\end{array}$ & $\mathrm{~N} / \mathrm{M}$ \\
\hline (18) CUT & $\begin{array}{l}\text { Online } \\
\text { learning }\end{array}$ & $\begin{array}{l}\text { Online } \\
\text { teaching }\end{array}$ & Institutional LMS & $\mathrm{N} / \mathrm{M}$ & $\begin{array}{ll}\text { Online } & \text { classes } \\
\text { due to } & \text { COVID- } \\
19^{30} & \\
\end{array}$ & $\begin{array}{l}\text { Data zero-rating }{ }^{31} \\
\& \text { free access to } \\
\text { LMS }\end{array}$ \\
\hline (19) DUT & $\begin{array}{l}\text { Remote } \\
\text { T\&L }\end{array}$ & $\begin{array}{l}\text { Remote } \\
\text { T\&L }\end{array}$ & $\begin{array}{l}\text { Moodle, MS } \\
\text { Teams, WhatsApp }\end{array}$ & $\begin{array}{l}\text { Remote } \text { T\&L } \\
\text { guide, support, } \\
\text { training, webinars } \\
\text { \& MOOCs for } \\
\text { staff; a guide for } \\
\text { students }\end{array}$ & $\begin{array}{l}\text { Shift to remote } \\
\text { T\&L due to } \\
\text { COVID-1932 }\end{array}$ & $\begin{array}{l}\text { Negotiating data } \\
\text { deals }^{33}\end{array}$ \\
\hline (20) VUT & $\begin{array}{l}\text { Online } \\
\text { instruction }\end{array}$ & $\begin{array}{l}\text { Online } \\
\text { instruction }\end{array}$ & Zoom \& Coursera & $\mathrm{N} / \mathrm{M}$ & $\begin{array}{l}\text { Online } \\
\text { transition due } \\
\text { to } \mathrm{CoV} \\
\end{array}$ & \\
\hline (21) MUT & $\begin{array}{l}\text { Online } \\
\text { classes }\end{array}$ & $\begin{array}{l}\text { Online } \\
\text { classes }\end{array}$ & & $\mathrm{N} / \mathrm{M}$ & $\begin{array}{l}\text { Online learning } \\
\text { due to COVID- } \\
19^{34}\end{array}$ & $\begin{array}{l}\text { Limited data zero- } \\
\text { rating offer }\end{array}$ \\
\hline
\end{tabular}

${ }^{*}=$ not mentioned; ${ }^{1}=$ online learning; ${ }^{2}=$ online teaching; ${ }^{3}=$ emergency remote learning; ${ }^{4}=$ emergency remote teaching; ${ }^{5}=$ From 20 April 2020; ${ }^{6}=$ all undergraduate courses except health sciences; ${ }^{7}=$ offered by leading mobile network companies; ${ }^{8}=$ valid for 30 days or for one month; ${ }^{9}=$ from 20 April $2020 ; 10=10 \mathrm{~GB}$ anytime \& 20GB between 12:00 midnight and 5am by one mobile network company; ${ }^{11}=$ from 30 March 2020 to 30 April $2020 ;{ }^{12}=$ zero-rating of the university's main webpage and the institutional LMS' s site; no mobile data charges by certain mobile network companies. NB: Zero-rating applicable for 30 days ${ }^{13}=$ from 20 April $2020 ;{ }^{14}=$ by four leading mobile network companies; ${ }^{15}=$ from 30 March 2020 with the exception of the Faculty of Medicine and Health Sciences; ${ }^{16}=$ negotiating with leading mobile network providers to zero-rate data to institutional LMS and streaming; ${ }^{17}$ = from 04 May 2020 (20 April 2020?) \& all students not to return to campus except final-year MBChB students; ${ }^{18}=$ provision of anytime managed and structured data to all students for four months (from 20 April 2020) ${ }^{19}=$ from 20 April 2020; ${ }^{20}=$ effective from the second term; ${ }^{21}=$ No charge on the first $500 \mathrm{MB}$ by four leading mobile network companies; ${ }^{22}=$ all registered students to receive $30 \mathrm{~GB}$ of data from mobile network operators with effect from 02 May 2020; for undergraduate students; student data \& zero-rating of certain websites by four leading mobile network operators (date or duration provided); ${ }^{25}=$ laptops to be made available 
to students in need as a reduced price; ${ }^{26}=$ making learning materials \& resources on Blackboard \& other digital platforms; ${ }^{27}=$ effective from 20 April 2020 subject to change; ${ }^{28}=$ for the provisioning of data, and delivering learning materials in the preferred format; ${ }^{29}=$ not specified; ${ }^{31}=$ from 30 March 2020 until 14 April $2020 ;{ }^{31}=$ by one mobile network companies \& ongoing negotiations with other network operators; ${ }^{32}=$ this is prior to 01 June 2020 when online features of blended/multi-modal learning system was going to be implemented; ${ }^{33}=$ with leading mobile network operators \& other related service providers; ${ }^{34}=$ with effect from 01 June $2020 ;{ }^{35}=$ from mobile service providers; ${ }^{36}=$ not mentioned

\section{Supplementary Files}

This is a list of supplementary files associated with this preprint. Click to download.

- AppendixA1.jpg

- AppendixA2.jpg

- AppendixA3.jpg

- AppendixA4.jpg

- AppendixA5.jpg

- AppendixA6.jpg

- AppendixB1.jpg

- AppendixB2.jpg

- AppendixA.docx

- AppendixB.docx 